\title{
Graphene oxide-assisted accumulation and layer-by-layer assembly of antibacterial peptide for sustained release applications \\ DOI:
}

10.1021/acsami.8b07417

\section{Document Version}

Accepted author manuscript

Link to publication record in Manchester Research Explorer

Citation for published version (APA):

Lu, J., Cao, M., Zhao, WJ., Wang, L., Zhang, Y., Li, R., Gong, H., \& Xu, H. (2018). Graphene oxide-assisted accumulation and layer-by-layer assembly of antibacterial peptide for sustained release applications. ACS Applied Materials and Interfaces, 10, 24937-24946. https://doi.org/10.1021/acsami.8b07417

Published in:

ACS Applied Materials and Interfaces

\section{Citing this paper}

Please note that where the full-text provided on Manchester Research Explorer is the Author Accepted Manuscript or Proof version this may differ from the final Published version. If citing, it is advised that you check and use the publisher's definitive version.

\section{General rights}

Copyright and moral rights for the publications made accessible in the Research Explorer are retained by the authors and/or other copyright owners and it is a condition of accessing publications that users recognise and abide by the legal requirements associated with these rights.

\section{Takedown policy}

If you believe that this document breaches copyright please refer to the University of Manchester's Takedown Procedures [http://man.ac.uk/04Y6Bo] or contact uml.scholarlycommunications@manchester.ac.uk providing relevant details, so we can investigate your claim.

\section{OPEN ACCESS}


CS Appl. Mater. Interfaces, 2018, 10 (29), pp 24937-24946

DOI: $10.1021 /$ acsami.8b07417

Publication Date (Web): June 29, 2018

\section{Graphene Oxide-Assisted Accumulation and Layer-by-Layer Assembly of}

\section{Antibacterial Peptide for Sustained Release Applications}

Meiwen Cao, ${ }^{* \dagger}$ Wenjing Zhao, ${ }^{\dagger}$ Lei Wang, ${ }^{\dagger}$ Ruiheng Li, ${ }^{\dagger}$ Haoning Gong, ${ }^{\dagger}$ Yu Zhang, ${ }^{\dagger}$ Hai Xu, ${ }^{* \dagger}$ and Jian R. Lu ${ }^{*,+}$

${ }^{\dagger}$ State Key Laboratory of Heavy Oil Processing and Centre for Bioengineering and Biotechnology, College of Chemical Engineering, China University of Petroleum (East China), 66 Changjiang West Road, Qingdao 266580, China

${ }^{\ddagger}$ Biological Physics Laboratory, School of Physics and Astronomy, University of Manchester, Schuster Building, Oxford Road, Manchester M13 9PL, U.K.

\section{Corresponding Authors}

* E-mail: mwcao@upc.edu.cn $\quad$ (M.C.); $\quad$ xuh@upc.edu.cn $\quad$ (H.X.); j.lu@manchester.ac.uk (J.R.L) 


\section{ABSTRACT:}

Fabrication of antibacterial materials with sustained release of active components is of great importance for long-term antibacterial applications. Graphene oxide (GO) has been found to be an excellent carrier for accumulating the antibacterial peptide of $\mathrm{G}(\mathrm{IIKK})_{4} \mathrm{I}-\mathrm{NH}_{2}$ and mediating its loading into the layer-by-layer (LBL) films for sustained release applications. $\mathrm{G}(\mathrm{IIKK})_{4} \mathrm{I}-\mathrm{NH}_{2}$ takes random coiled conformation in monomeric state below $0.17 \mathrm{mM}$ but self-assembles into supramolecular aggregates with $\alpha$-helical secondary structure at higher concentrations. It can bind onto GO surface in both monomeric and aggregate states to form stable GO@G(IIKK) $)_{4} \mathrm{I}-\mathrm{NH}_{2}$ composites. Upon binding the local amphiphilic environment of GO surface induces a conformational transition of $\mathrm{G}(\mathrm{IIKK})_{4} \mathrm{I}-\mathrm{NH}_{2}$ monomers from random coils to $\alpha$-helix. The aggregate binding enhances the loading amount greatly. $1 \mathrm{mg}$ GO can load as high as $1.7 \mathrm{mg}$ of peptide at saturation. This enables the GO@G(IIKK) $)_{4} \mathrm{I}-\mathrm{NH}_{2}$ composites to serve as reservoirs for the sustained release of active $\mathrm{G}(\mathrm{IIKK})_{4} \mathrm{I}-\mathrm{NH}_{2}$ monomers. Moreover, G(IIKK) $)_{4} \mathrm{I}-\mathrm{NH}_{2}$ itself shows low efficiency in LBL assembly, while the $\mathrm{GO} @ \mathrm{G}(\mathrm{IIKK})_{4} \mathrm{I}-\mathrm{NH}_{2}$ composites are ideal LBL assembling units with highly enhanced loading efficiency of $\mathrm{G}(\mathrm{IIKK})_{4} \mathrm{I}-\mathrm{NH}_{2}$. The LBL films involving degradable poly $(\beta$-amino esters $)$ can realize the sustained release of $\mathrm{G}(\mathrm{IIKK})_{4} \mathrm{I}-\mathrm{NH}_{2}$ for bacteria killing in a well-controlled manner. This study demonstrates an efficient strategy for fabrication of long-durable antibacterial materials and surface coatings by using GO as the carrier for drug accumulation and loading.

KEYWORDS: Sustained release, Antibacterial peptides, Self-assembly, Graphene oxide, Layer-by-layer 


\section{INTRODUCTION}

For conventional drug dosing methods of tablets, sprays, or injections, drug levels usually fluctuate between a maximum and a minimum when repeated administration is undertaken. This has potential risks of either toxicity if the maximum drug concentration is above the toxic level or inefficacy if the minimum drug concentration is below the minimum effective level. The latter may also make the drug resistance more easily happen because intermittent drug inefficacy is one of the main causes of drug resistance. ${ }^{1}$

Controlled release systems that can release drug in a fixed, predetermined pattern are appreciated for overcoming these shortcomings. A sustained release system can be designed to release drug slowly and continuously so as to maintain a uniform drug concentration for a prolonged time period by a single dosage. This will lead to smaller dosages and fewer side effects and also lower the chances of inducing drug resistance. $^{2}$

For a sustained release system, a high drug loading amount and a controllable drug release process are two important aspects that enable long-term applications. The two criteria both call for suitable drug carriers and formulations. Recently, graphene oxide (GO), the single- or few-layer graphite oxide sheets, ${ }^{3-9}$ has been intensively investigated as drug carriers due to several advantages. Firstly, GO has higher drug loading capacity due to its large surface area as well as diverse binding mechanisms with drug molecules, e.g. hydrophobic interaction, electrostatic interaction, hydrogen bonding, and $\pi-\pi$ stacking. ${ }^{7,10-14}$ Secondly, it shows good biocompatibility and can effectively deliver the drug into cells. ${ }^{7,15-16}$ Furthermore, GO has a lot of active sites 
such as hydroxyl and carboxyl groups, which enable convenient immobilization of target molecules on the surface for its controlled delivery. ${ }^{17-18}$ These aspects all make GO a promising material for controlled drug delivery and release.

Layer-by-layer (LBL) assembly is a simple and promising strategy for fabrication of sustained release coatings because the active components can be loaded into the films by repeated adsorption process. An efficient LBL process usually requires polycations and polyanions with infinite binding sites to enable a stable adsorption layer, ${ }^{19}$ while the small molecules are usually difficult to be loaded into the LBL films with a high amount due to its non-polymeric nature. ${ }^{20-22}$ Some small molecules, e.g. antibacterial peptides, have been incorporated into the LBL multilayers either by covalent binding or by noncovalent assembly. ${ }^{23-28}$ However, it remains a great challenge about how to improve the loading efficiency and how to maximize the loading amount. ${ }^{29}$

Recently we have carried out studies on a class of short cationic $\alpha$-helical peptides, $\mathrm{G}(\mathrm{IIKK})_{\mathrm{n}} \mathrm{I}-\mathrm{NH}_{2}(\mathrm{n}=1-4){ }^{30-32}$ They have repeated hydrophilic/hydrophobic residues, which can align along two opposite sides to give a folded conformation with amphiphilic structure, mimicking the structure and function of natural antimicrobial peptides (AMPs). ${ }^{33-35}$ These peptides can kill both Gram-positive and Gram-negative bacteria effectively either by membrane permeabilization or by acting on certain cytoplasmic targets. ${ }^{31,36-37}$

Here, we report the fabrication of antibacterial materials with the sustained release of the antibacterial peptide of $\mathrm{G}(\mathrm{IIKK})_{4} \mathrm{I}-\mathrm{NH}_{2}$. $\mathrm{G}(\mathrm{IIKK})_{4} \mathrm{I}-\mathrm{NH}_{2}$ was found to self-assemble into ordered supramolecular aggregates, which can then bind onto GO 
nanosheets to form stable $\mathrm{GO} @ \mathrm{G}(\mathrm{IIKK})_{4} \mathrm{I}-\mathrm{NH}_{2}$ composites with a high loading amount. These composites can not only be used as reservoirs for the sustained release of active $\mathrm{G}(\mathrm{IIKK})_{4} \mathrm{I}-\mathrm{NH}_{2}$ monomers, but also can mediate the successful incorporation of a high amount of $\mathrm{G}(\mathrm{IIKK})_{4} \mathrm{I}-\mathrm{NH}_{2}$ into the layer-by-layer (LBL) films so as to construct antibacterial coatings. The study demonstrates an efficient strategy for the fabrication of long-durable antibacterial bulk materials and surface coatings by using GO as the carrier for drug accumulation and loading.

\section{EXPERIMENTAL}

\subsection{Materials}

The peptides of $\mathrm{G}(\mathrm{IIKK})_{4} \mathrm{I}-\mathrm{NH}_{2}$ and $\mathrm{W}(\mathrm{IIKK})_{4} \mathrm{I}-\mathrm{NH}_{2}$ (purity > 96\%) were purchased from Shanghai Top-Peptide Biotechnology Co. Ltd. GO and poly( $\beta$-amino esters) (poly $\beta$ ) were synthesized according to the literature methods. ${ }^{38-39}$ Bacteria of Escherichia coli (ATCC 25922), Staphylococcus aureus (ATCC 6538), and Pseudomonas aeruginosa (ATCC 9027) were obtained from the American Type Culture Collection (ATCC) company. E. coli, S. aureus, and P. aeruginosa were grown in Tryptic soy broth (TSB). All of the other chemicals were purchased from Sigma-Aldrich and used as received. Milli-Q water $(18 \mathrm{M} \Omega \mathrm{cm})$ was used for all the experiments.

\subsection{Preparation of GO Sheets}

GO sheets were prepared by a modified Hummers' method. ${ }^{40}$ Firstly, 6 g of $\mathrm{KMnO}_{4}$ was slowly added into a mixture of graphite powder $(2 \mathrm{~g}), \mathrm{NaNO}_{3}(1 \mathrm{~g})$ and $\mathrm{H}_{2} \mathrm{SO}_{4}$ (> $95 \%, 46 \mathrm{~mL}$ ) under stirring. During the process the temperature was kept below $20^{\circ} \mathrm{C}$ with an ice bath. After complete mixing the temperature was increased to $35{ }^{\circ} \mathrm{C}$ and 
incubated for $20 \mathrm{~h}$. Then $92 \mathrm{~mL}$ of water was added into the mixtures and the temperature was increased to $98{ }^{\circ} \mathrm{C}$ and then incubated for $15 \mathrm{~min}$. After that $280 \mathrm{ml}$ of pure water and $5 \mathrm{ml}$ of $\mathrm{H}_{2} \mathrm{O}_{2}$ was further added into the system for dilution. The solid mixture was then centrifuged and washed and the remaining graphite oxide and normal graphite powder were collected. The raw GO suspension was obtained by applying an ultrasonic process to isolate the thin layers from oxidized graphite sheets. By suitable ultrasonic treatment the size of the GO sheets can be controlled. The solid residual was removed by another centrifugation process. Finally, a dialysis process is applied to get rid of soluble impurities.

\subsection{Electrical Conductivity}

Electrical conductivity was measured on a DDS-307 conductometer (Shanghai Leici Corporation, China) at $25.0 \pm 0.2{ }^{\circ} \mathrm{C}$. The conductivity was plotted as a function of the $\mathrm{G}(\mathrm{IIKK})_{4} \mathrm{I}-\mathrm{NH}_{2}$ concentration. The critical aggregation concentration (CAC) was determined by intersection of the two linear fits in different concentration regions below and above the CAC.

\subsection{Transmission Electron Microscopy (TEM) and cryo-TEM}

Both negative-staining TEM and cryo-TEM images were obtained on a JEM 1400Plus (JEOL) electron microscope at an accelerating voltage of $120 \mathrm{kV}$. The negative-staining samples were prepared by casting the sample solution onto the copper grid for adsorption of $5 \mathrm{~min}$ and then negatively stained with $2 \%$ uranyl acetate for $2 \mathrm{~min}$. Cryo-TEM samples were prepared with an environment-controlled vitrification system. Firstly, $5 \mu \mathrm{L}$ of sample solution was deposited on a copper grid with a laced support coating and the excess solution was wicked away with filter 
papers to leave only a thin solution film on the mesh holes. Then the specimen was vitrified by quickly dipping into the liquid ethane of $-165{ }^{\circ} \mathrm{C}$. The specimen was stored and transferred to a Gatan 626 cryogenic sample holder in the liquid nitrogen and imaged at $-174{ }^{\circ} \mathrm{C}$.

\subsection{Atomic Force Microscopy (AFM)}

AFM measurements were performed on a MultiMode Nanoscope IVa system (Digital Instruments, Santa Barbara, CA). Tapping mode images were captured using TESP-V2 silicon probes (Bruker, Germany) with a nominal spring constant of $42 \mathrm{~N}$ $\mathrm{m}^{-1}$. For sample preparation, $5-10 \mu \mathrm{L}$ of the sample solution was deposited onto a freshly cleaved mica surface for adsorption of $\sim 30 \mathrm{~s}$. Then, the sample was dried under a nitrogen stream. The images were analyzed using the vendor-supplied software (version 1.40, Bruker).

\subsection{Scanning Electron Microscopy (SEM)}

SEM images were obtained on a JEOL JSM-840 electron microscope operating at 15 $\mathrm{kV}$. Before imaging the LBL films were mounted on a SEM sample holder and sputter coated with a thin layer of platinum.

\subsection{UV-Vis Measurements}

UV-Vis measurements were performed on a UV-1700 spectrophotometer (Phama Spec, Shimadzu) at room temperature. The spectra were collected in the wavelength range of $200-800 \mathrm{~nm}$. For the $\mathrm{GO} @ \mathrm{G}(\mathrm{IIKK})_{4} \mathrm{I}-\mathrm{NH}_{2}$ mixed solutions, the absorption value at $400 \mathrm{~nm}$ was used for turbidity evaluation. For the $\mathrm{W}(\mathrm{IIKK})_{4} \mathrm{I}-\mathrm{NH}_{2}$ solutions, the absorption value at $280 \mathrm{~nm}$ was used for producing the standard curve as well as 
calculating the $\mathrm{W}(\mathrm{IIKK})_{4} \mathrm{I}-\mathrm{NH}_{2}$ concentration.

\subsection{Circular Dichroism (CD)}

CD spectra were recorded on a MOS-450/AF-CD spectrophotometer (BioLogic, France) at room temperature. For the solution samples, a $0.5 \mathrm{~mm}$ quartz cells were used and scans were collected in a wavelength range of 190-280 nm. In contrast, the LBL films were assembled on the quartz slides and measured directly. Each scan was repeated three times and the averaged value was given as the final result.

\subsection{Zeta Potential $(\zeta)$}

The $\zeta$ values were obtained on a ZEN3600 Nano-ZS equipment (Malvern Instruments, Worcestershire, UK) at room temperature. A clear disposable capillary cell with model number of DTS1060C was used.

\subsection{Spectroscopic Ellipsometry (SE)}

A UVISEL spectroscopic ellipsometer (Jobin-Yvon) was used to follow the thickness growth of the LBL films. The grazing incidence angle was set at $70^{\circ}$. The ellipsometry measures the polarization difference between the incident light and outgoing light in terms of an amplitude ratio $(\tan \Psi)$ and phase difference $(\Delta)$. Light can be considered as two orthogonal components, $p$ wave and $s$ wave, which are parallel and perpendicular to the plane of incidence, respectively. The Fresnel reflection coefficient of these two components, $r_{p}$ and $r_{s}$, can be determined as follow: ${ }^{41}$

$$
r_{p} / r_{s}=\tan \Psi e^{i \Delta}
$$


The reflection coefficient can be also written in terms of material thickness (d) and refractive index (n), thus we can obtain one of these coupled parameters if we know the other. In our work, the refractive index is defined using a Cauchy model:

$$
n(\lambda)=A+\frac{B}{\lambda^{2}}+\frac{C}{\lambda^{4}}
$$

where $\lambda$ is the light wavelength and $\mathrm{A}, \mathrm{B}$ and $\mathrm{C}$ are constants.

\subsection{Antibacterial Activity Determination}

Antibacterial activities of $\mathrm{G}(\mathrm{IIKK})_{4} \mathrm{I}-\mathrm{NH}_{2}$ and the $\mathrm{GO} @ \mathrm{G}(\mathrm{IIKK})_{4} \mathrm{I}-\mathrm{NH}_{2}$ composites were evaluated by the tetrazolium reduction (MTT) test and the minimum inhibitory concentration (MIC) was determined. Briefly, $\mathrm{G}(\mathrm{IIKK})_{4} \mathrm{I}-\mathrm{NH}_{2}$ or the GO@G(IIKK) $)_{4} \mathrm{I}-\mathrm{NH}_{2}$ composite was dissolved in buffer solution of $\mathrm{pH} 7.4$ and sterilized under ultraviolet radiation for a few hours. $200 \mu \mathrm{l}$ of bacterial dispersion after overnight culture was pipetted into a 96-well plate. The optical density at 600 $\mathrm{nm}\left(\mathrm{OD}_{600}\right)$ was measured using a Sunrise microplate reader (Tecan Group Ltd.). The bacterial cultures were calibrated to the $\mathrm{OD}_{600}$ of 0.8 , and 1:2000 (v/v) diluted in the broth. Peptide solutions were two-fold diluted using buffer solution in the 96-well plates with the total volume of $100 \mu \mathrm{l}$ in each well. $100 \mu \mathrm{l}$ of the diluted bacterial inoculum was pipetted into each well for mixing with the peptide solution. The bacterial cultures were incubated at $37^{\circ} \mathrm{C}$ with shaking at $100 \mathrm{rpm}$ for $18 \mathrm{~h}$, followed by measurements of the $\mathrm{OD}_{600}$. The MICs were determined as the lowest AMP concentrations of antibiotics at which bacterial growth cannot be observed. ${ }^{42}$ Triplicate experiments were performed with three technical replicates for each measurement. Errors were calculated by standard deviations of the replicate measurements. 


\subsection{LBL Film Construction}

LBL films were constructed by using the $\mathrm{GO} @ \mathrm{G}(\mathrm{IIKK})_{4} \mathrm{I}-\mathrm{NH}_{2}$ composites (as a positively charged unit), polyacrylic acid (PAA, polyanion), and poly( $\beta$-amino esters) (poly $\beta$, polycation) as three assembling units. Poly $\beta$ is a hydrolytically degradable polycation with ester bonds, which can be used in LBL assembly to control the film degradation and release of active components. ${ }^{19,24,39,43-48}{ }^{1}$ H-NMR analysis was used to confirm the structure of the final product (Figure S1). Each LBL cycle contains a sequential dipping of the substrate in the solution of poly $\beta$, PAA, the mixed solution of $\mathrm{GO}(0.15 \mathrm{mg} / \mathrm{mL})$ and $\mathrm{G}(\mathrm{IIKK})_{4} \mathrm{I}-\mathrm{NH}_{2}(1.0 \mathrm{mM})$, and PAA again for adsorption of 5 min. The sample was rinsed with water after each adsorption process. The resultant LBL film is denoted as (poly $\left.\beta / \mathrm{PAA} / \mathrm{GO} @ \mathrm{G}(\mathrm{IIKK})_{4} \mathrm{I}-\mathrm{NH}_{2} / \mathrm{PAA}\right)_{\mathrm{n}}$, where $\mathrm{n}$ is the cycle number. $\mathrm{G}(\mathrm{IIKK})_{4} \mathrm{I}-\mathrm{NH}_{2}$ solution was also used for LBL assembly for comparison.

\subsection{Drug Loading and Release}

For easy determination of the peptide concentration, the N-terminal glycine residue of $\mathrm{G}(\mathrm{IIKK})_{4} \mathrm{I}-\mathrm{NH}_{2}$ was substituted by tryptophan (W) to produce $\mathrm{W}(\mathrm{IIKK})_{4} \mathrm{I}-\mathrm{NH}_{2}$, which has strong UV-vis signal at $280 \mathrm{~nm}$ and facilitates concentration determination. For loading efficiency determination, various amount of $\mathrm{W}(\mathrm{IIKK})_{4} \mathrm{I}-\mathrm{NH}_{2}$ was dissolved in $2 \mathrm{~mL}$ of Hepes solution with $0.3 \mathrm{mg} / \mathrm{ml} \mathrm{GO}$ and incubated in a shaker at $37{ }^{\circ} \mathrm{C}$ for 30 h. Then, the dispersion was centrifuged at $15,000 \mathrm{rpm}$ for $30 \mathrm{~min}$. The absorbance of the supernatant at $280 \mathrm{~nm}$ was measured and used to calculate the non-adsorbed $\mathrm{W}(\mathrm{IIKK})_{4} \mathrm{I}-\mathrm{NH}_{2}$ concentration by referring to a standard curve (Figure S2, Supporting Information). The loading efficiency was calculated by the formula "the loading 
efficiency $=($ the dosing amount - the non-adsorbed amount $) /$ the dosing amount". The precipitate obtained was then carefully rinsed and used to produce the release profile with the dialysis method $\left(\mathrm{M}_{\mathrm{W}} \mathrm{CO}=14 \mathrm{kDa}\right)$ against $20 \mathrm{ml}$ of Hepes buffer. The release reservoir was kept under constant stirring. At various time points $2 \mathrm{~mL}$ of the dialyzate was taken out for concentration determination and an equal volume of the fresh Hepes buffer was replenished to it.

For determining the peptide release from the LBL film, a glass slide coated with (poly $\left.\beta / \mathrm{PAA} / \mathrm{GO} @ \mathrm{~W}(\mathrm{IIKK})_{4} \mathrm{I}-\mathrm{NH}_{2} / \mathrm{PAA}\right)_{15}$ multilayers was immersed in $20.0 \mathrm{~mL}$ of Hepes buffered solution of $\mathrm{pH}$ 7.0. At various time points the absorbance of the solution was recorded and used for calculating the released $\mathrm{W}(\mathrm{IIKK})_{4} \mathrm{I}-\mathrm{NH}_{2}$ amount. In another experiment, a mixture of $\mathrm{G}(\mathrm{IIKK})_{4} \mathrm{I}-\mathrm{NH}_{2}$ and $\mathrm{W}(\mathrm{IIKK})_{4} \mathrm{I}-\mathrm{NH}_{2}$ at the molar ratio of 95:5 was used for LBL assembly, where $\mathrm{W}(\mathrm{IIKK})_{4} \mathrm{I}-\mathrm{NH}_{2}$ was used as a reference for determining the released $\mathrm{G}(\mathrm{IIKK})_{4} \mathrm{I}-\mathrm{NH}_{2}$ concentration in the following experiment of peptide release from the LBL films.

\subsection{Kirby-Bauer Disk Diffusion Assay}

The antibacterial activity of the (poly $\left.\beta / \mathrm{PAA} / \mathrm{GO} @ \mathrm{G}(\mathrm{IIKK})_{4} \mathrm{I}-\mathrm{NH}_{2} / \mathrm{PAA}\right)_{\mathrm{n}} \mathrm{LBL}$ films was assessed by the Kirby-Bauer method. $500 \mu \mathrm{L}$ of the bacterial suspension in the logarithmic growth phase with a density of $10^{6} \sim 10^{7} \mathrm{CFU} / \mathrm{ml}$ was added to the agar-containing culture medium and mixed evenly. After about 10 min the culture medium was solidified. The glass slides coated with (poly $\left.\beta / \mathrm{PAA} / \mathrm{G}(\mathrm{IIKK})_{4} \mathrm{I}-\mathrm{NH}_{2} / \mathrm{PAA}\right)_{\mathrm{n}}$ or $\quad\left(\text { poly } \quad \beta / \mathrm{PAA} / \mathrm{GO} @ \mathrm{G}(\mathrm{IIKK})_{4} \mathrm{I}-\mathrm{NH}_{2} / \mathrm{PAA}\right)_{\mathrm{n}} \quad$ were attached to the solid medium. A clean glass slide was used as control. Bacterial inhibition zones were measured after 24 hours of incubation at $30^{\circ} \mathrm{C}$. 


\section{RESULTS AND DISCUSSION}

\subsection{Self-Assembly of G(IIKK) $)_{4} \mathrm{I}-\mathrm{NH}_{2}$}

We have shown that $\mathrm{G}(\mathrm{IIKK})_{4} \mathrm{I}-\mathrm{NH}_{2}$ exhibits antibacterial activity at quite low concentrations of $<10 \mu \mathrm{M}$, where it exists and functions as monomers. ${ }^{30}$ Here, we report that $\mathrm{G}(\mathrm{IIKK})_{4} \mathrm{I}-\mathrm{NH}_{2}$ can also self-assemble into supramolecular aggregates at higher concentrations. The CAC of $\mathrm{G}(\mathrm{IIKK})_{4} \mathrm{I}-\mathrm{NH}_{2}$ was determined to be about 0.17 $\mathrm{mM}$ from the electrical conductivity measurement (Figure 1a). Both AFM and TEM results show that $\mathrm{G}(\mathrm{IIKK})_{4} \mathrm{I}-\mathrm{NH}_{2}$ self-assembled into short fibrils with height of $\sim 2.0$ $\mathrm{nm}$ at $0.5 \mathrm{mM}$ (Figure 1b). These structures exist in a concentration range of up to 5.0 mM. With further increasing the concentration, $\mathrm{G}(\mathrm{IIKK})_{4} \mathrm{I}-\mathrm{NH}_{2}$ formed long fibrils with length of over one micrometer and height of about $4.0 \mathrm{~nm}$ (Figure 1c and 1d). At $25.0 \mathrm{mM}$ the entanglement of the fibrils can even cause the gelation of the solution and give a self-supporting hydrogel, as verified by the test-tube inverting method (the inset of Figure 1c). The increase in both length and diameter indicates the gradual growth of the self-assembled structures at different stages.
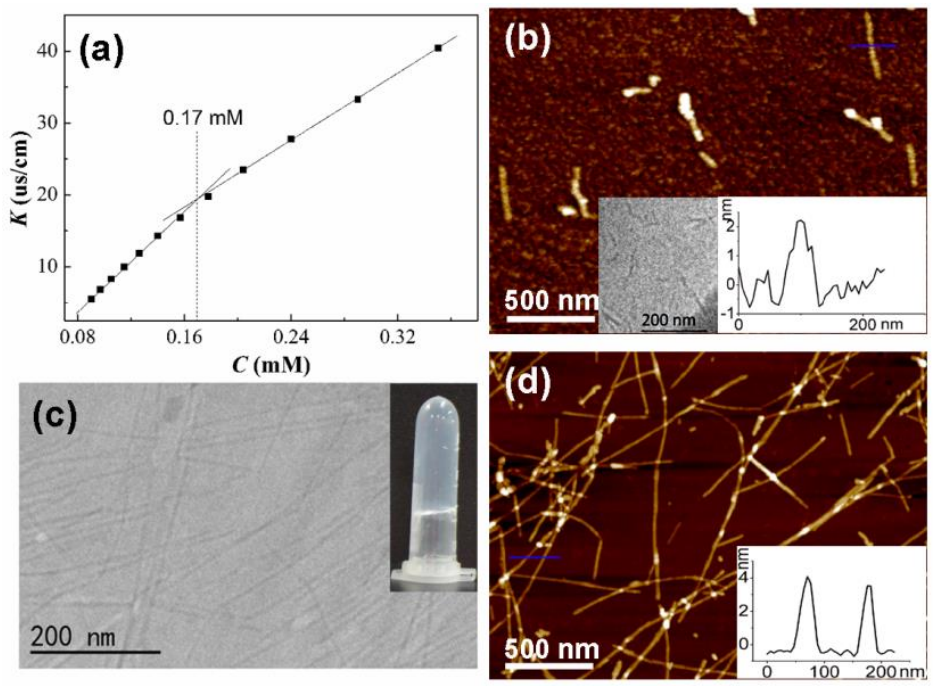

Figure 1. (a) Determination of the CAC of $\mathrm{G}(\mathrm{IIKK})_{4} \mathrm{I}-\mathrm{NH}_{2}$ in aqueous solution of $\mathrm{pH}$ of $4.0 \pm 0.3$ from the plot of electrical conductivity $v s$ peptide concentration. (b) AFM 
image of the self-assembled structures of $\mathrm{G}(\mathrm{IIKK})_{4} \mathrm{I}-\mathrm{NH}_{2}$ at $0.5 \mathrm{mM}$. The insets show the cryo-TEM image and the section analysis corresponding to the blue line. (c) Cryo-TEM and (d) AFM images of the self-assembled structures of G(IIKK) $)_{4} \mathrm{I}-\mathrm{NH}_{2}$ at the gelling concentration of $25.0 \mathrm{mM}$. The insets of images $\mathrm{c}$ and $\mathrm{d}$ show the photograph of the self-supporting hydrogel and the corresponding section analysis, respectively.

\subsection{Formation of the GO@G(IIKK) $)_{4} \mathrm{I}-\mathrm{NH}_{2}$ Composites}

GO are single- or few-layer graphite oxide sheets with basic structural network of polyaromatic benzene rings. The morphology and size of the GO sheets were characterized by AFM (Figure S3a). They give a size distribution of 100-2000 nm in lateral dimension (Figure S3b). Except for some wrinkled and overlapped areas, the sheets give a thickness value of $0.85-1.2 \mathrm{~nm}$ (Figure S3c), corresponding to the single-layer sheets. They produce negative $\zeta$ values of $-(42 \pm 10) \mathrm{mV}$ due to the presence of many carboxylic acid groups and phenol hydroxyl groups at the surface (Figure S3d). ${ }^{49-52}$ These hydrophilic groups and the negative charges enable the good dispersion of GO sheets in aqueous solution. Upon adsorption of $\mathrm{G}(\mathrm{IIKK})_{4} \mathrm{I}-\mathrm{NH}_{2}$, however, the size and $\zeta$ value of the $\mathrm{GO} @ \mathrm{G}(\mathrm{IIKK})_{4} \mathrm{I}-\mathrm{NH}_{2}$ composites exhibit significant variation. The turbidity results (Figure 2a) show that below $0.05 \mathrm{mM}$ of $\mathrm{G}(\mathrm{IIKK})_{4} \mathrm{I}-\mathrm{NH}_{2}$, the solution absorbance keeps a low value of $\sim 0.15$ and only slightly increases with increasing peptide concentration. The solution remained clear at this concentration range. However, in the $\mathrm{G}(\mathrm{IIKK})_{4} \mathrm{I}-\mathrm{NH}_{2}$ concentration range of $0.05 \mathrm{mM}$ to $0.1 \mathrm{mM}$, the turbidity shows a sharp increase. And from $0.1 \mathrm{mM}$ to $0.5 \mathrm{mM}$, the absorbance keeps at high levels and precipitates were found. Then above $1.0 \mathrm{mM}$ the absorbance decreases with redispersion of the precipitates and the solution returns to 
be translucent again. During complexation the $\zeta$ value of the $\mathrm{GO} @ \mathrm{G}(\mathrm{IIKK})_{4} \mathrm{I}-\mathrm{NH}_{2}$ composites increased gradually with increasing peptide concentration (Fig. 2b). However, it remains negative at peptide concentrations of below $0.1 \mathrm{mM}$, indicating that the GO@G(IIKK) $)_{4} \mathrm{I}-\mathrm{NH}_{2}$ composites take net negative charges. Then above 0.1 $\mathrm{mM}$ the $\zeta$ value turns to be positive, indicating a charge reversal of the $\mathrm{GO} @ \mathrm{G}(\mathrm{IIKK})_{4} \mathrm{I}-\mathrm{NH}_{2}$ composites. The $\zeta$ potential reaches equilibrium of about +30 $\mathrm{mV}$ at the peptide concentration of $\sim 0.5 \mathrm{mM}$.
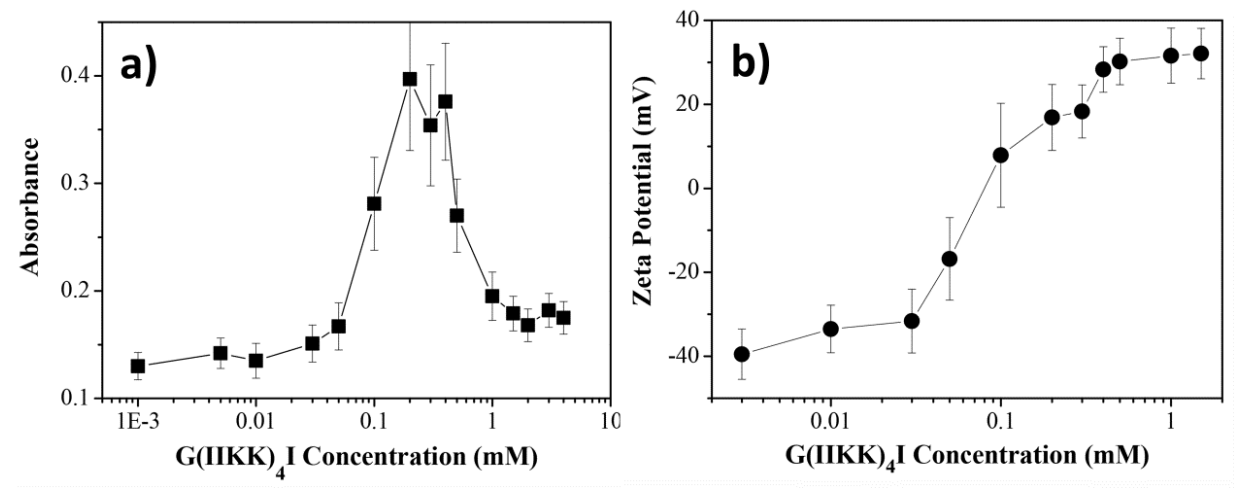

Figure 2. Turbidity (a) and zeta potential (b) values of the GO/G(IIKK) $)_{4} \mathrm{I}-\mathrm{NH}_{2}$ mixed dispersions with the concentration of GO fixed at $0.15 \mathrm{mg} / \mathrm{mL}$ while the concentration of $\mathrm{G}(\mathrm{IIKK})_{4} \mathrm{I}-\mathrm{NH}_{2}$ was gradually increased.

Both turbidity and $\zeta$ results give clues to the process of $\mathrm{GO} / \mathrm{G}(\mathrm{IIKK})_{4} \mathrm{I}-\mathrm{NH}_{2}$ complexation. Since GO is negatively charged and $\mathrm{G}(\mathrm{IIKK})_{4} \mathrm{I}-\mathrm{NH}_{2}$ is positively charged, binding of $\mathrm{G}(\mathrm{IIKK})_{4} \mathrm{I}-\mathrm{NH}_{2}$ onto the $\mathrm{GO}$ surface will lead to charge neutralization and reversal. At $\mathrm{G}(\mathrm{IIKK})_{4} \mathrm{I}-\mathrm{NH}_{2}$ concentrations of below $0.05 \mathrm{mM}$, the GO negative charges are in significant excess comparing to the positive charges of the adsorbed $\mathrm{G}(\mathrm{IIKK})_{4} \mathrm{I}-\mathrm{NH}_{2}$ molecules, therefore, the $\mathrm{GO} @ \mathrm{G}(\mathrm{IIKK})_{4} \mathrm{I}-\mathrm{NH}_{2}$ composites maintain a high amount of net negative charges and are dispersed well in solution. In the concentration range of $0.05-0.5 \mathrm{mM}$, the negative charges of $\mathrm{GO}$ are comparable with the positive charges of $\mathrm{G}(\mathrm{IIKK})_{4} \mathrm{I}-\mathrm{NH}_{2}$ in number. Neutralization of the two 
species results in poor dispersion and precipitation of the $\mathrm{GO} @ \mathrm{G}(\mathrm{IIKK})_{4} \mathrm{I}-\mathrm{NH}_{2}$ composites and produces the maximum turbidity region. Then above $0.5 \mathrm{mM}$, the positive charges of $\mathrm{G}(\mathrm{IIKK})_{4} \mathrm{I}-\mathrm{NH}_{2}$ are in great excess comparing to the negative charges of GO, therefore, the $\mathrm{GO} @ \mathrm{G}(\mathrm{IIKK})_{4} \mathrm{I}-\mathrm{NH}_{2}$ composites take high net positive charges and become redispersed into the solution again.

The CD spectra of the G(IIKK) $)_{4} \mathrm{I}-\mathrm{NH}_{2}$ solution and the GO/G(IIKK $)_{4} \mathrm{I}-\mathrm{NH}_{2}$ mixed solution characterize the secondary structures (Figure 3). At concentrations of 0.05 $\mathrm{mM}$ and $0.1 \mathrm{mM}$, which are below the CAC, the CD spectra show a negative peak at about $197 \mathrm{~nm}$, typical of random coiled conformation. ${ }^{30,53}$ While at concentrations above the CAC, that is, $0.5 \mathrm{mM}$ and $1.0 \mathrm{mM}$, the $\mathrm{CD}$ spectra give two negative peaks, one at $\sim 208 \mathrm{~nm}$ and another at $200-225 \mathrm{~nm}$, characteristic of $\alpha$-helix conformation. ${ }^{30,}$ ${ }^{53}$ The results suggest that $\mathrm{G}(\mathrm{IIKK})_{4} \mathrm{I}-\mathrm{NH}_{2}$ takes random coils in monomeric state but turns into $\alpha$-helix when forming aggregates. However, upon binding to GO surface, both $\mathrm{G}(\mathrm{IIKK})_{4} \mathrm{I}-\mathrm{NH}_{2}$ monomers and aggregates adopt $\alpha$-helix secondary structures, as indicated by the two peaks at $204-208 \mathrm{~nm}$ and $220-225 \mathrm{~nm}$ in all of the cases. Clearly, the peptide monomers had a conformational transition from random coils to $\alpha$-helix before and after binding onto GO surface. 

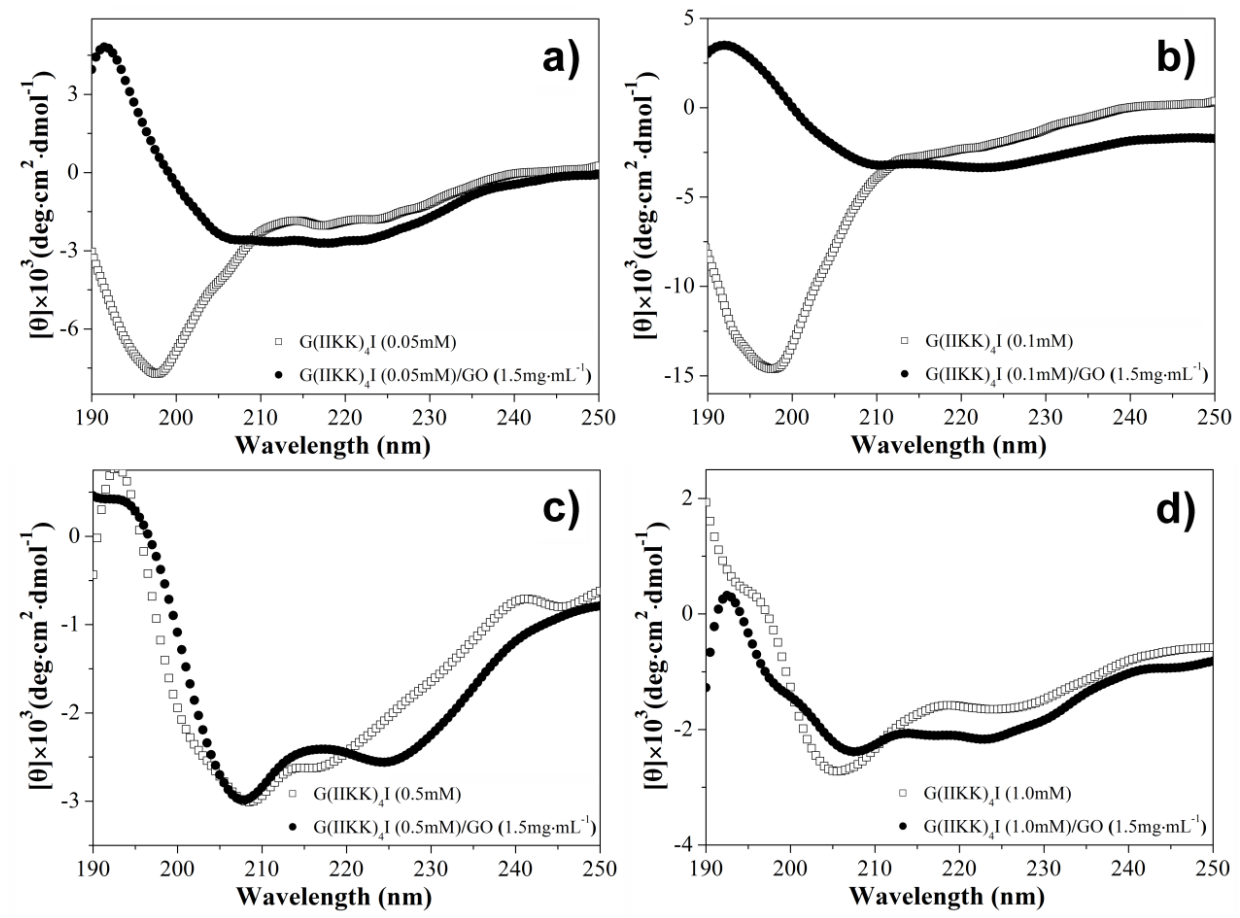

Figure 3. $\mathrm{CD}$ spectra of the $\mathrm{GO} / \mathrm{G}(\mathrm{IIKK})_{4} \mathrm{I}-\mathrm{NH}_{2}$ mixed solutions as well as the corresponding $\mathrm{G}(\mathrm{IIKK})_{4} \mathrm{I}-\mathrm{NH}_{2}$ solutions at different concentrations, (a) $0.05 \mathrm{mM}$, (b) $0.1 \mathrm{mM}$, (c) $0.5 \mathrm{mM}$, and (d) $1.0 \mathrm{mM}$.

$\mathrm{G}(\mathrm{IIKK})_{4} \mathrm{I}-\mathrm{NH}_{2}$ monomers and aggregates may well have different binding mechanisms on GO surface. We have shown that $\mathrm{G}(\mathrm{IIKK})_{4} \mathrm{I}-\mathrm{NH}_{2}$ takes random coiled conformation in aqueous solutions but form $\alpha$-helix when inserting into negatively charged lipid membranes. ${ }^{30}$ In fact, GO has similarity to lipids in the nature of amphiphilicity and it can be viewed as a sheet-like surfactant. ${ }^{54-57}$ For G(IIKK) $)_{4} \mathrm{I}-\mathrm{NH}_{2}$ monomers, they bind onto GO surface with the positive Lys residues electrostatically anchoring at the surface negative sites and the Ile residues hydrophobically interacting with the surface benzene rings. Such interactions induce $\mathrm{G}(\mathrm{IIKK})_{4} \mathrm{I}-\mathrm{NH}_{2}$ folding into the $\alpha$-helix conformation with Lys and Ile residues aligning along two opposite sides, forming an amphiphilic structure similar to the one predicted by Schiffer-Edmundson wheel projection (Figure S4). ${ }^{30}$ While for $\mathrm{G}(\mathrm{IIKK})_{4} \mathrm{I}-\mathrm{NH}_{2}$ aggregates, since the 
hydrophobic Ile residues are embedded in the inner core and the positively charged Lys residues are left outward, they will bind on GO by mainly electrostatic interaction. Once in contact, however, structural deformation and rearrangement may occur, driven again by hydrophobic interaction. Thus, the interacting processes are broadly similar even though the exact molecular processes may differ.

Figure 4 shows the morphologies of the GO sheets and the GO@G(IIKK) $)_{4} \mathrm{I}-\mathrm{NH}_{2}$ composites. The GO sheets again have a height of around $1.0 \mathrm{~nm}$ and the surfaces are very smooth except some folding areas. However, when interacting with $\mathrm{G}(\mathrm{IIKK})_{4} \mathrm{I}-\mathrm{NH}_{2}$, a large amount of $\mathrm{G}(\mathrm{IIKK})_{4} \mathrm{I}-\mathrm{NH}_{2}$ nanospheres and fibrils are adsorbed on the GO surface. The section profile of Figure $4 \mathrm{~b}$ shows heights of about $1.0 \mathrm{~nm}$ for the GO sheets and $1.0-2.0 \mathrm{~nm}$ for the $\mathrm{G}(\mathrm{IIKK})_{4} \mathrm{I}-\mathrm{NH}_{2}$ aggregates. The $\mathrm{G}(\mathrm{IIKK})_{4} \mathrm{I}-\mathrm{NH}_{2}$ aggregates sometimes distribute relatively even on the GO surface (Fig. $4 \mathrm{~b}$ and $4 \mathrm{~d}$ ), but in most cases they are more ready to locate at the edges of GO sheets (Fig. 4c and 4e). The reason behind this is that most negatively charged carboxylic acid groups distribute at the edges and few charged groups on the basal plane, ${ }^{49-52}$ thus the charged GO sheet edges being the main binding sites for $\mathrm{G}(\mathrm{IIKK})_{4} \mathrm{I}-\mathrm{NH}_{2}$ aggregates. Moreover, the adsorbed aggregates may induce folding of the GO sheets, especially at the edge areas as denoted by the black arrows in Figure $4 b$. 

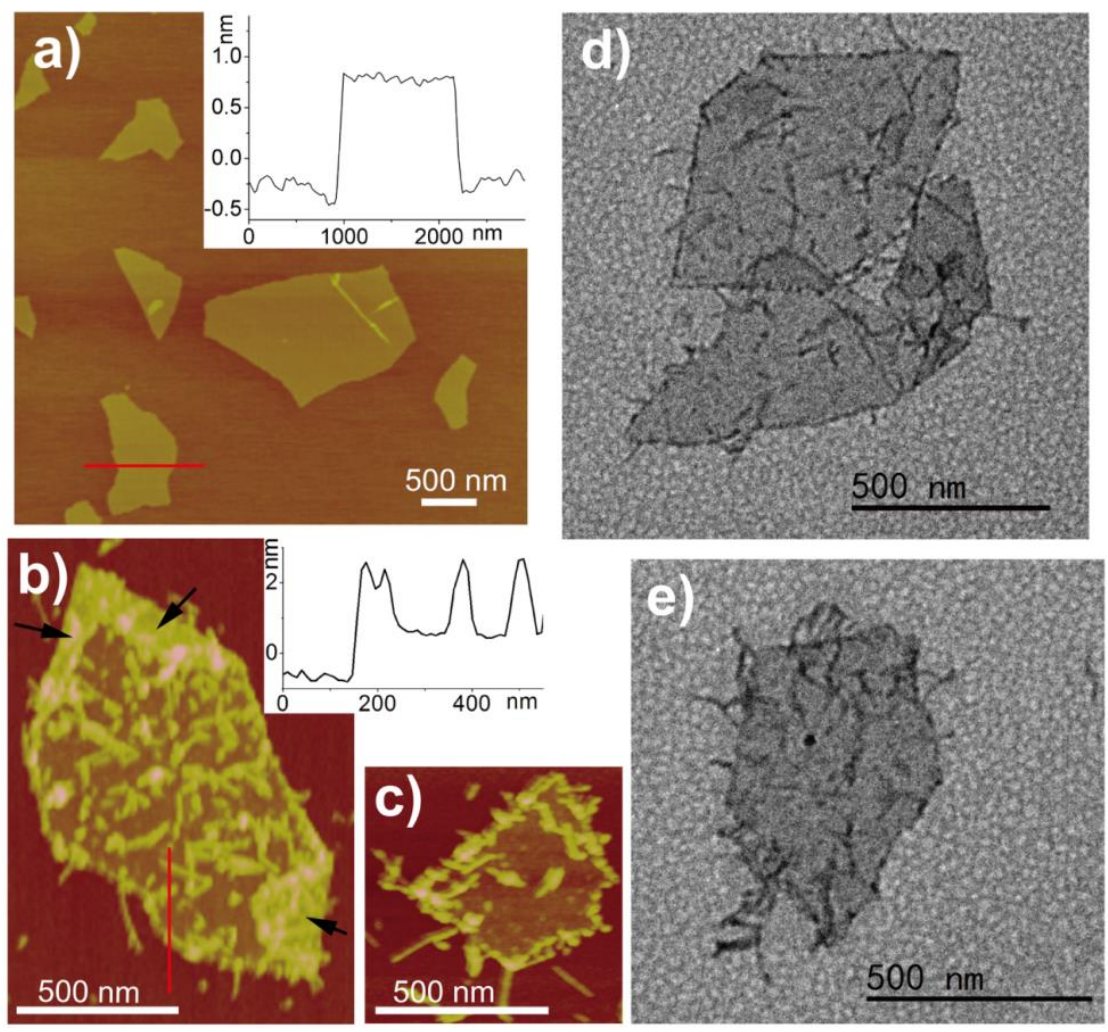

Figure 4. AFM morphologies of the GO sheets (a). AFM (b, c) and negative-staining TEM (d, e) morphologies of the GO@ $\mathrm{G}(\mathrm{IIKK})_{4} \mathrm{I}-\mathrm{NH}_{2}$ composites produced from the mixed solution of $\mathrm{GO}(0.15 \mathrm{mg} / \mathrm{mL})$ and $\mathrm{G}(\mathrm{IIKK})_{4} \mathrm{I}-\mathrm{NH}_{2}(1.0 \mathrm{mM})$.

\subsection{Antibacterial Properties of the GO@G(IIKK) $)_{4} \mathrm{I}-\mathrm{NH}_{2}$ Composites}

$\mathrm{G}(\mathrm{IIKK})_{4} \mathrm{I}-\mathrm{NH}_{2}$ is a highly efficient antibiotic that has quite low MIC values against several bacteria. ${ }^{30}$ It is interesting to explore how its antibacterial ability will be affected by complexing to GO. Free G(IIKK) $)_{4} \mathrm{I}-\mathrm{NH}_{2}$ shows $\mathrm{MIC}$ of $\sim 6 \mu \mathrm{M}$ and $\sim 12$ $\mu \mathrm{M}$ againt E. coli and S. aureus, respectively, as seen from the inset of Figure 5a. However, for the GO/G(IIKK) $)_{4} \mathrm{I}-\mathrm{NH}_{2}$ mixed system, the MIC against $E$. coli and $S$. aureus is $100 \pm 10 \mu \mathrm{M}$ and $80 \pm 7 \mu \mathrm{M}$, respectively, as measured by the $\mathrm{G}(\mathrm{IIKK})_{4} \mathrm{I}-\mathrm{NH}_{2}$ concentration. These values are about 10 times higher than those of free $\mathrm{G}(\mathrm{IIKK})_{4} \mathrm{I}-\mathrm{NH}_{2}$. The significantly increased MIC value is reasoned as follows. The binding and complexing of $\mathrm{G}(\mathrm{IIKK})_{4} \mathrm{I}-\mathrm{NH}_{2}$ molecules with bacterial membrane is 
crucial for bacterial killing. ${ }^{30}$ Such interactions need involvement of both the positive charges and the hydrophobic segment of $\mathrm{G}(\mathrm{IIKK})_{4} \mathrm{I}-\mathrm{NH}_{2}$ molecules. Therefore, free $\mathrm{G}(\mathrm{IIKK})_{4} \mathrm{I}-\mathrm{NH}_{2}$ molecules should be the most efficient species for killing bacteria. However, for the GO/G(IIKK) $)_{4} \mathrm{I}-\mathrm{NH}_{2}$ mixtures, most of the $\mathrm{G}(\mathrm{IIKK})_{4} \mathrm{I}-\mathrm{NH}_{2}$ molecules were adsorbed and confined on the GO surface. This greatly lowered the concentration of free $\mathrm{G}(\mathrm{IIKK})_{4} \mathrm{I}-\mathrm{NH}_{2}$ monomers that could interact with bacteria and thus to result in significant increase of the apparent MIC value.
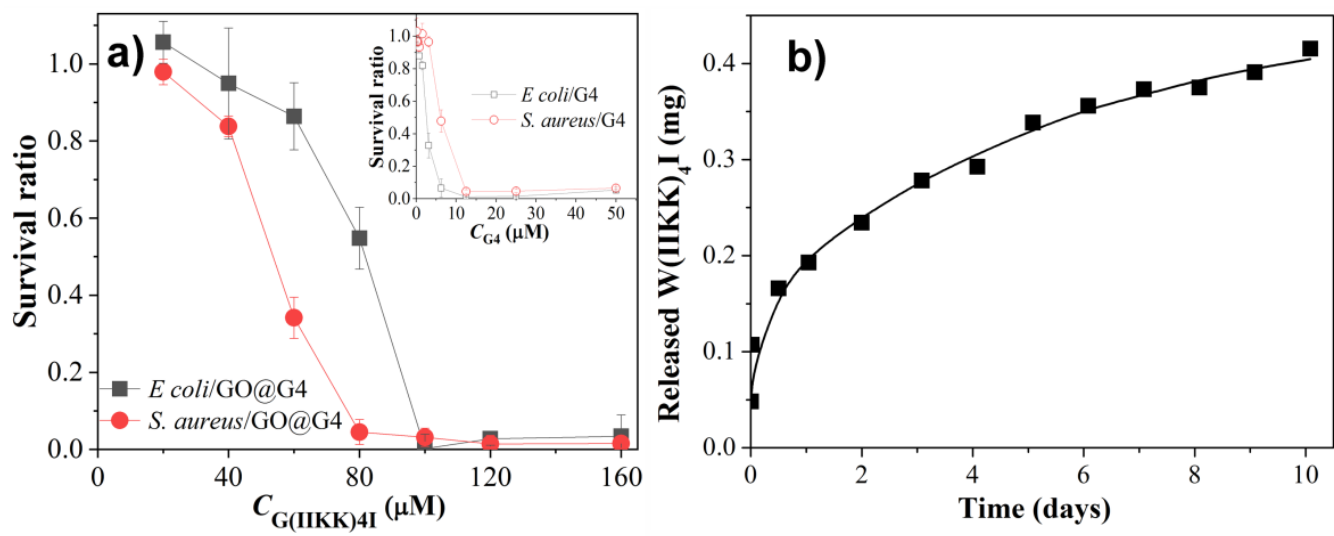

Figure 5. (a) The MTT results showing the antibacterial effects of the GO/G(IIKK) $)_{4} \mathrm{I}-\mathrm{NH}_{2}$ mixed system against bacteria of $E$. coli (Gram-negative) and $S$. aureus (Gram-positive). The inset shows the results of free $\mathrm{G}(\mathrm{IIKK})_{4} \mathrm{I}-\mathrm{NH}_{2}$ for comparison. (b) The peptide release profile from the GO@W(IIKK) $)_{4} \mathrm{I}-\mathrm{NH}_{2}$ composites.

Noting that the free $\mathrm{G}(\mathrm{IIKK})_{4} \mathrm{I}-\mathrm{NH}_{2}$ concentration can be regulated by controlling the equilibrium of molecular exchange between $\mathrm{G}(\mathrm{IIKK})_{4} \mathrm{I}-\mathrm{NH}_{2}$ monomers and the $\mathrm{GO} @ \mathrm{G}(\mathrm{IIKK})_{4} \mathrm{I}-\mathrm{NH}_{2}$ composites, we suggest that the latter can be used as reservoirs for sustained $\mathrm{G}(\mathrm{IIKK})_{4} \mathrm{I}-\mathrm{NH}_{2}$ release. The loading efficiency and release profile of the peptide on GO sheets were then determined by using $\mathrm{W}(\mathrm{IIKK})_{4} \mathrm{I}-\mathrm{NH}_{2}$ for easy concentration determination. It was found that $1 \mathrm{mg}$ of GO can adsorb as high as 1.70 
$\pm 0.15 \mathrm{mg}$ of peptide molecules at saturation (Figure S5). The high loading amount assures the capacity of the GO@peptide composites as reservoirs for peptide release. Figure $5 \mathrm{~b}$ shows the peptide release profile from the $\mathrm{GO} @ \mathrm{~W}(\mathrm{IIKK})_{4} \mathrm{I}-\mathrm{NH}_{2}$ composites. The accumulative released amount of the peptide increases gradually with time for up to 10 days, clearly showing the excellent sustained release ability of the GO@peptide composites.

\subsection{Construction of Antibacterial LBL Films by Using the GO@G(IIKK) $)_{4} I-\mathrm{NH}_{2}$}

\section{Composites as Assembling Units}

LBL is a simple and efficient method to fabricate functional surface coatings. However, it usually requires polyelectrolytes or building blocks with massive charges. $\mathrm{G}(\mathrm{IIKK})_{4} \mathrm{I}-\mathrm{NH}_{2}$ itself does not assure efficient LBL assembly due to the limited charge number. Here, the GO@G(IIKK) $)_{4} \mathrm{I}-\mathrm{NH}_{2}$ composites were found to be excellent assembling units for LBL construction that can highly enhance the loading efficiency of $\mathrm{G}(\mathrm{IIKK})_{4} \mathrm{I}-\mathrm{NH}_{2}$. The LBL films were constructed by using the $\mathrm{GO} @ \mathrm{G}(\mathrm{IIKK})_{4} \mathrm{I}-\mathrm{NH}_{2}$ composites as a positively charged unit, PAA as a polyanion and poly $\beta$ as a polycation. Free $\mathrm{G}(\mathrm{IIKK})_{4} \mathrm{I}-\mathrm{NH}_{2}$ was also used for LBL construction as a control. Figure 6a shows the thickness growth profiles of the LBL films. In both cases the film thickness shows a linear dependence on the number of deposition cycle. However, the thickness of the (poly $\left.\beta / \mathrm{PAA} / \mathrm{GO} @ \mathrm{G}(\mathrm{IIKK})_{4} \mathrm{I}-\mathrm{NH}_{2} / \mathrm{PAA}\right)_{\mathrm{n}}$ film increases more sharply than that of the (poly $\left.\beta / \mathrm{PAA} / \mathrm{G}(\mathrm{IIKK})_{4} \mathrm{I}-\mathrm{NH}_{2} / \mathrm{PAA}\right)_{\mathrm{n}}$ film, which indicates that more components were loaded into the LBL film by using the composites instead of $\mathrm{G}(\mathrm{IIKK})_{4} \mathrm{I}-\mathrm{NH}_{2}$ itself. The $\mathrm{CD}$ spectra of the (poly $\left.\beta / \mathrm{PAA} / \mathrm{GO} @ \mathrm{G}(\mathrm{IIKK})_{4} \mathrm{I}-\mathrm{NH}_{2} / \mathrm{PAA}\right)_{\mathrm{n}}$ film exhibit typical $\alpha$-helix signal with two negative peaks at 208 and $222 \mathrm{~nm}$ (Figure 6b). The absolute peak intensity at $222 \mathrm{~nm}$ 
also gives a linear dependence on the cycle number. The results show that $\mathrm{G}(\mathrm{IIKK})_{4} \mathrm{I}-\mathrm{NH}_{2}$ can be more efficiently loaded into the LBL multilayers by using GO@G(IIKK $)_{4} \mathrm{I}-\mathrm{NH}_{2}$ composites. The formation of the composites not only can accumulate $\mathrm{G}(\mathrm{IIKK})_{4} \mathrm{I}-\mathrm{NH}_{2}$ on $\mathrm{GO}$ surface but also enhance the stability of $\mathrm{G}(\mathrm{IIKK})_{4} \mathrm{I}-\mathrm{NH}_{2}$ aggregates in LBL process.

The surface morphology of the (poly $\left.\beta / \mathrm{PAA} / \mathrm{GO} @ \mathrm{G}(\mathrm{IIKK})_{4} \mathrm{I}-\mathrm{NH}_{2} / \mathrm{PAA}\right)_{50}$ film was characterized by both SEM and AFM and the results are shown in Figure 6c. The film surface has many wrinkles, which resulted from the adsorbed GO sheets. The (poly $\left.\beta / \mathrm{PAA} / \mathrm{GO} @ \mathrm{G}(\mathrm{IIKK})_{4} \mathrm{I}-\mathrm{NH}_{2} / \mathrm{PAA}\right)_{50}$ multilayer shows a compact film with thickness of $\sim 1.2 \mu \mathrm{m}$, as seen from the cross-sectional image in Figure $6 \mathrm{~d}$. This is a clear sign of the efficient LBL film construction.
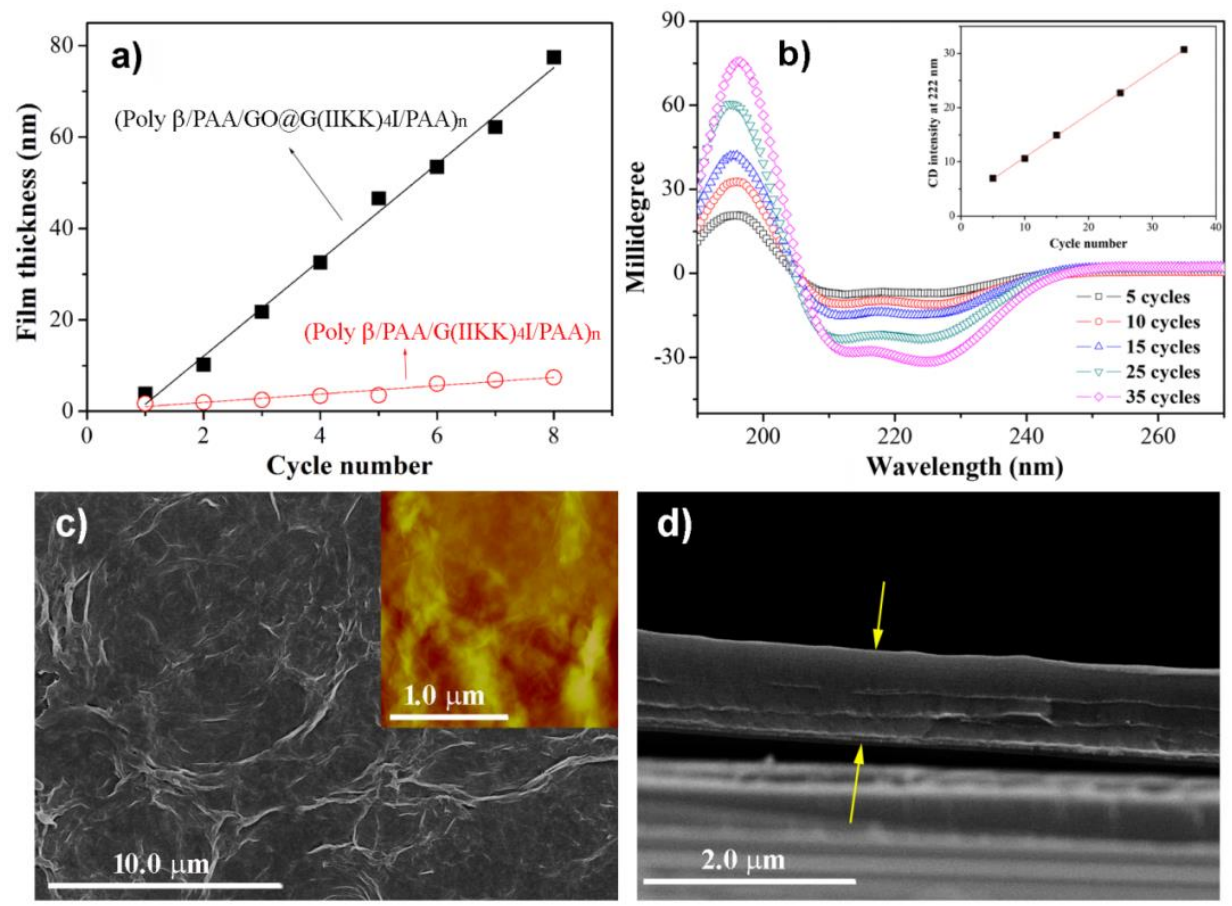

Figure 6. (a) The thickness growth of the (poly $\left.\beta / \mathrm{PAA} / \mathrm{GO} @ \mathrm{G}(\mathrm{IIKK})_{4} \mathrm{I}-\mathrm{NH}_{2} / \mathrm{PAA}\right)_{\mathrm{n}}$ and (poly $\left.\beta / \mathrm{PAA} / \mathrm{G}(\mathrm{IIKK})_{4} \mathrm{I}-\mathrm{NH}_{2} / \mathrm{PAA}\right)_{\mathrm{n}}$ LBL films. (b) CD spectra of the (poly $\left.\beta / \mathrm{PAA} / \mathrm{GO} @ \mathrm{G}(\mathrm{IIKK})_{4} \mathrm{I}-\mathrm{NH}_{2} / \mathrm{PAA}\right)_{\mathrm{n}}$ film. The inset shows the linear dependence of 
the absolute CD intensity at $222 \mathrm{~nm}$ on the deposition cycle number. (c) SEM and AFM morphology images of the (poly $\left.\beta / \mathrm{PAA} / \mathrm{GO} @ \mathrm{G}(\mathrm{IIKK})_{4} \mathrm{I}-\mathrm{NH}_{2} / \mathrm{PAA}\right)_{50}$ film. (d) Cross-sectional SEM image of the (poly $\left.\beta / \mathrm{PAA} / \mathrm{GO} @ \mathrm{G}(\mathrm{IIKK})_{4} \mathrm{I}-\mathrm{NH}_{2} / \mathrm{PAA}\right)_{50}$ film.

The peptide release from the (poly $\left.\beta / \mathrm{PAA} / \mathrm{GO} @ \mathrm{~W}(\mathrm{IIKK})_{4} \mathrm{I}-\mathrm{NH}_{2} / \mathrm{PAA}\right)_{15}$ film was further investigated by incubation in buffer solution of $\mathrm{pH} 7.0$ (Figure 7a). In the first day, the peptide release speed was slightly higher, probably involving a release burst due to the loosely bound peptides. In the following several days, the release amount showed approximately a linear increase with time, indicating successful degradation of the LBL film to enable the peptide escape. The release process lasted for about 7 days and beyond that the release amount did not increase further. The results clearly show that the loaded peptide can be successfully released from the LBL film in a well-controlled manner and the release length scale can be quite large. The CD spectrum of the solution after incubating with a (poly $\left.\beta / \mathrm{PAA} / \mathrm{GO} @ \mathrm{G}(\mathrm{IIKK})_{4} \mathrm{I} / \mathrm{PAA}\right)_{15}$ film shows a single negative minimum at $\sim 200 \mathrm{~nm}$, indicating random coiled conformation (Figure $7 \mathrm{~b}$ ). The result shows that the released $\mathrm{G}(\mathrm{IIKK})_{4} \mathrm{I}-\mathrm{NH}_{2}$ molecules mainly present as free monomers, e.g., the functional bacteria-killing species. 

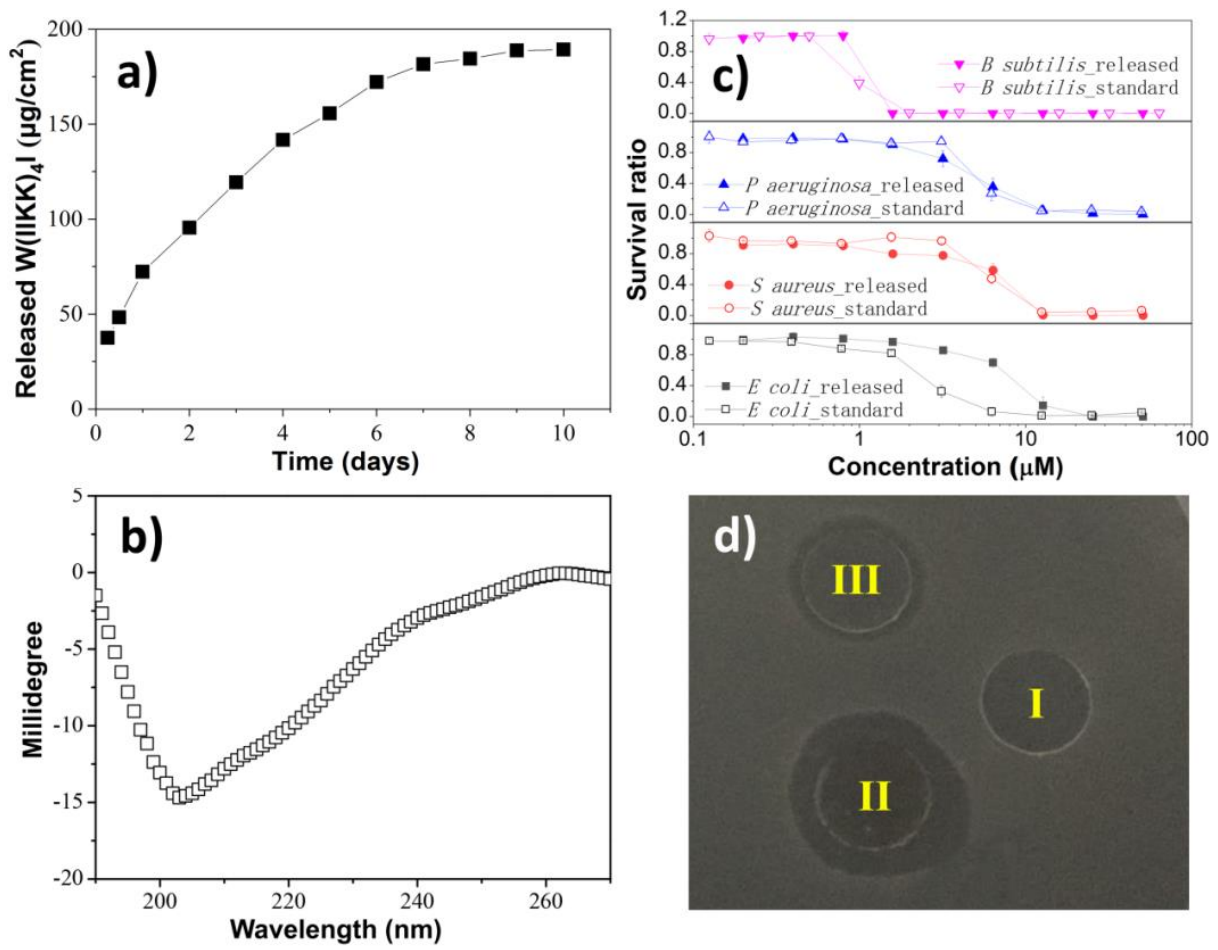

Figure 7. (a) Time-dependent release profile of $\mathrm{W}(\mathrm{IIKK})_{4} \mathrm{I}-\mathrm{NH}_{2}$ from the (poly $\left.\beta / \mathrm{PAA} / \mathrm{GO} @ \mathrm{~W}(\mathrm{IIKK})_{4} \mathrm{I}-\mathrm{NH}_{2} / \mathrm{PAA}\right)_{15}$ film $(2 \mathrm{~cm} \times 4 \mathrm{~cm})$ when incubating in $20.0 \mathrm{~mL}$ of Hepes solution of $\mathrm{pH}$ 7.0. (b) The CD spectrum of the solution after incubation with a (poly $\left.\beta / \mathrm{PAA} / \mathrm{GO} @ \mathrm{G}(\mathrm{IIKK})_{4} \mathrm{I} / \mathrm{PAA}\right)_{15}$ film for $12 \mathrm{~h}$. (c) The MTT results showing the antibacterial efficiency of the LBL-released $\mathrm{G}(\mathrm{IIKK})_{4} \mathrm{I}-\mathrm{NH}_{2}$ against different bacteria. Free $\mathrm{G}(\mathrm{IIKK})_{4} \mathrm{I}-\mathrm{NH}_{2}$ was used as control. (d) Kirby-Bauer disk diffusion assay by recording the inhibition zones after bacterial culture at $30^{\circ} \mathrm{C}$ for 24 hours. (i) bare glass slide, (ii) glass slide coated with (poly $\left.\beta / \mathrm{PAA} / \mathrm{GO} @ \mathrm{G}(\mathrm{IIKK})_{4} \mathrm{I}-\mathrm{NH}_{2} / \mathrm{PAA}\right)_{15}$ film, and (iii) glass slide coated with (poly $\left.\beta / \mathrm{PAA} / \mathrm{G}(\mathrm{IIKK})_{4} \mathrm{I}-\mathrm{NH}_{2} / \mathrm{PAA}\right)_{15}$ film.

One crucial aspect is that whether the peptide molecules released from the LBL films retain their antibacterial capability. The antibacterial efficiency of the LBL-released $\mathrm{G}(\mathrm{IIKK})_{4} \mathrm{I}-\mathrm{NH}_{2}$ against different bacteria was then assessed by MTT assay. The results show that the LBL-released $\mathrm{G}(\mathrm{IIKK})_{4} \mathrm{I}-\mathrm{NH}_{2}$ gives $\mathrm{MIC}$ values of about 2.0, 
$10.5,10.5$, and $11.5 \mu \mathrm{M}$ for the four bacteria of B. subtilis, P. aeruginosa, S. aureus, and E. coli, respectively, which are approximately the same as the MIC values obtained from free $\mathrm{G}(\mathrm{IIKK})_{4} \mathrm{I}-\mathrm{NH}_{2}$ (Figure 7c). This clearly shows that the LBL-released $\mathrm{G}(\mathrm{IIKK})_{4} \mathrm{I}-\mathrm{NH}_{2}$ molecules retain their high bacteria-killing efficiency. Kirby-Bauer disk diffusion assay was further performed to confirm the antibacterial ability of the LBL films (Figure 7d). The bare glass slide gives no antibacterial zone. The glass slide coated with (poly $\left.\beta / \mathrm{PAA} / \mathrm{G}(\mathrm{IIKK})_{4} \mathrm{I}-\mathrm{NH}_{2} / \mathrm{PAA}\right)_{15}$ multilayers gives the antibacterial zone of about $1 \mathrm{~mm}$, and the glass slide coated with the (poly $\left.\beta / \mathrm{PAA} / \mathrm{GO} @ \mathrm{G}(\mathrm{IIKK})_{4} \mathrm{I}-\mathrm{NH}_{2} / \mathrm{PAA}\right)_{15}$ film produces antibacterial zone of about $3 \mathrm{~mm}$. Clearly, the LBL film constructed with GO@G(IIKK) $)_{4} \mathrm{I}-\mathrm{NH}_{2}$ composites gives much higher antibacterial efficiency. The results confirm that the loading amount of $\mathrm{G}(\mathrm{IIKK})_{4} \mathrm{I}-\mathrm{NH}_{2}$ in the LBL multilayers can be greatly increased by using the $\mathrm{GO} @ \mathrm{G}(\mathrm{IIKK})_{4} \mathrm{I}-\mathrm{NH}_{2}$ composites as assembling units.

The advantages of the LBL systems loaded with antibacterial peptides for controlled release are as follows. Firstly, the loading amount of antimicrobial peptides can be easily tuned by varying the cycle number of the LBL process. Therefore, the saturation limit of the peptide release can be greatly increased if more cycles were applied. Secondly, the release speed of the antimicrobial peptide from the LBL film can be adjusted by changing the content of degradable polymer (poly $\beta$ here) in the multilayers. Moreover, the assembly-disassembly equilibrium between peptide aggregates and monomers can also be used to control the release profile.

\section{CONCLUSIONS}

The self-assembly of $\mathrm{G}(\mathrm{IIKK})_{4} \mathrm{I}-\mathrm{NH}_{2}$, its complexing with $\mathrm{GO}$ and use of the 
GO@G(IIKK $)_{4} \mathrm{I}-\mathrm{NH}_{2}$ composites in the LBL assembly have been studied. $\mathrm{G}(\mathrm{IIKK})_{4} \mathrm{I}-\mathrm{NH}_{2}$ molecules exist as monomers with random coiled conformation at lower concentrations while self-assembled into supramolecular aggregates with $\alpha$-helix secondary structure at concentrations above the CAC. Being positively charged, $\mathrm{G}(\mathrm{IIKK})_{4} \mathrm{I}-\mathrm{NH}_{2}$ can bind onto the negatively charged GO surface and form stable supramolecular $\mathrm{GO} @ \mathrm{G}(\mathrm{IIKK})_{4} \mathrm{I}-\mathrm{NH}_{2}$ composites. During complex formation the amphiphilic nature of GO sheets induces a secondary structural transition of $\mathrm{G}(\mathrm{IIKK})_{4} \mathrm{I}-\mathrm{NH}_{2}$ monomers from random coils to $\alpha$-helix. The aggregate binding on GO surface greatly enhances the loading amount of $\mathrm{G}(\mathrm{IIKK})_{4} \mathrm{I}-\mathrm{NH}_{2}$, which further enables the $\mathrm{GO} @ \mathrm{G}(\mathrm{IIKK})_{4} \mathrm{I}-\mathrm{NH}_{2}$ composites to act as reservoirs for the sustained release of the active antibacterial molecules. Moreover, the $\mathrm{GO} @ \mathrm{G}(\mathrm{IIKK})_{4} \mathrm{I}-\mathrm{NH}_{2}$ composites work as excellent assembling units for LBL assembly, which can increase the loading efficiency of $\mathrm{G}(\mathrm{IIKK})_{4} \mathrm{I}-\mathrm{NH}_{2}$ in the multilayers greatly. The LBL films involving degradable poly $\beta$ can realize sustained release of $\mathrm{G}(\mathrm{IIKK})_{4} \mathrm{I}-\mathrm{NH}_{2}$ for bacterial killing in a well-controlled manner.

The present study aids the development of bulk materials or surface coatings with long-term antibacterial capability via sustained drug release. By probing into the self-assembly behavior of the antibacterial peptide $\mathrm{G}(\mathrm{IIKK})_{4} \mathrm{I}-\mathrm{NH}_{2}$ and its complexation with GO, this study not only unravels the mechanistic interaction process but also provides potential materials for sustained release applications via the controlled loading and release of the small antibacterial molecules from constructing the LBL multilayers. Noting that graphitic carbon nitride has specific photoactivity and can form composites with $\mathrm{GO},{ }^{58-59}$ one interesting future research topic is to produce photoactive antibacterial materials by involving graphitic carbon nitride in 
the composites.

\section{Notes}

The authors declare no competing financial interest.

\section{Supporting Information Available}

The supporting information includes the molecular structure and ${ }^{1} \mathrm{H}-\mathrm{NMR}$ spectrum of $\operatorname{poly}\left(\beta\right.$-amino ester), the standard curve for calculation of $\mathrm{W}(\mathrm{IIKK})_{4} \mathrm{I}-\mathrm{NH}_{2}$ concentration, AFM and zeta potential results of the GO sheets, the Schiffer-Edmundson wheel projection of $\mathrm{G}(\mathrm{IIKK})_{4} \mathrm{I}-\mathrm{NH}_{2}$, and the loading efficiency of $\mathrm{W}(\mathrm{IIKK})_{4} \mathrm{I}-\mathrm{NH}_{2}$ on GO. This material is available free of charge via the Internet at http://pubs.acs.org.

ACKNOWLEDGEMENTSThis work was supported by the National Natural Science Foundation of China under grant numbers 21473255 and 21003160, and the Fundamental Research Funds for the Central Universities (17CX02050), and the Key Laboratory of Applied Surface and Colloid Chemistry (Shaanxi Normal University). We also acknowledge the UK Physical Sciences and Engineering Research Council (EPSRC, EP/F062966/1), Innovate UK (KTP008143, KTP009043) and the Graphene Grand Challenges by the University of Manchester for funding support.

\section{- REFERENCES}

(1) Langer, R.; Peppas, N. Chemical and Physical Structure of Polymers as Carriers for Controlled Release of Bioactive Agents: A Review. J. Macromol. Sci.-R.M.C.P. 1983, 23, 61-126.

(2) Pundir, S.; Badola, A.; Sharma, D. Sustained Release Matrix Technology and Recent Advance in Matrix Drug Delivery System: A Review. Int. J. Drug Res. Tech. 
2013, 3, 12-20.

(3) Stankovich, S.; Dikin, D. A.; Dommett, G. H. B.; Kohlhaas, K. M.; Zimney, E. J.; Stach, E. A.; Piner, R. D.; Nguyen, S. T.; Ruoff, R. S. Graphene-Based Composite Materials. Nature 2006, 442, 282-286.

(4) Becerril, H. A.; Mao, J.; Liu, Z.; Stoltenberg, R. M.; Bao, Z.; Chen, Y. Evaluation of Solution-Processed Reduced Graphene Oxide Films as Transparent Conductors. ACS Nano 2008, 2, 463-470.

(5) Li, X.; Wang, X.; Zhang, L.; Lee, S.; Dai, H. Chemically Derived, Ultrasmooth Graphene Nanoribbon Semiconductors. Science 2008, 319, 1229-1232.

(6) Bonaccorso, F.; Sun, Z.; Hasan, T.; Ferrari, A. C. Graphene Photonics and Optoelectronics. Nat Photon 2010, 4, 611-622.

(7) Byun, E.; Lee, H. Enhanced Loading Efficiency and Sustained Release of Doxorubicin from Hyaluronic Acid/Graphene Oxide Composite Hydrogels by a Mussel-Inspired Catecholamine. J. Nanosci. Nanotechnol. 2014, 14, 7395-7401.

(8) Zhang, B.; Yang, X.; Wang, Y.; Zhai, G. Heparin Modified Graphene Oxide for $\mathrm{pH}-$ Sensitive Sustained Release of Doxorubicin Hydrochloride. Mater. Sci. Eng., C 2017, 75, 198-206.

(9) de Sousa, I. P.; Buttenhauser, K.; Suchaoin, W.; Partenhauser, A.; Perrone, M.; Matuszczak, B.; Bernkop-Schnürch, A. Thiolated Graphene Oxide as Promising Mucoadhesive Carrier for Hydrophobic Drugs. Int. J. Pharm. 2016, 509, 360-367.

(10) Zhou, T.; Zhou, X.; Xing, D. Controlled Release of Doxorubicin from Graphene Oxide Based Charge-Reversal Nanocarrier. Biomaterials 2014, 35, 4185-4194.

(11) Goenka, S.; Sant, V.; Sant, S. Graphene-Based Nanomaterials for Drug Delivery and Tissue Engineering. J. Control. Release 2014, 173, 75-88.

(12) Yang, X.; Zhang, X.; Liu, Z.; Ma, Y.; Huang, Y.; Chen, Y. High-Efficiency Loading and Controlled Release of Doxorubicin Hydrochloride on Graphene Oxide. $J$. Phys. Chem. C 2008, 112, 17554-17558.

(13) Shim, G.; Kim, M.-G.; Park, J. Y.; Oh, Y.-K. Graphene-Based Nanosheets for Delivery of Chemotherapeutics and Biological Drugs. Adv. Drug Deliver. Rev. 2016, 105, 205-227.

(14) Chung, C.; Kim, Y.-K.; Shin, D.; Ryoo, S.-R.; Hong, B. H.; Min, D.-H. Biomedical Applications of Graphene and Graphene Oxide. Acc. Chem. Res. 2013, 46, 2211-2224.

(15) Tao, C.-a.; Wang, J.; Qin, S.; Lv, Y.; Long, Y.; Zhu, H.; Jiang, Z. Fabrication of $\mathrm{pH}$-sensitive Graphene Oxide-Drug Supramolecular Hydrogels as Controlled Release Systems. J. Mater. Chem. 2012, 22, 24856-24861.

(16) Zhang, L.; Xia, J.; Zhao, Q.; Liu, L.; Zhang, Z. Functional Graphene Oxide as a Nanocarrier for Controlled Loading and Targeted Delivery of Mixed Anticancer Drugs. Small 2010, 6, 537-544.

(17) Yang, X.; Wang, Y.; Huang, X.; Ma, Y.; Huang, Y.; Yang, R.; Duan, H.; Chen, Y. Multi-Functionalized Graphene Oxide Based Anticancer Drug-Carrier with Dual-Targeting Function and pH-Sensitivity. J. Mater. Chem. 2011, 21, 3448-3454.

(18) Yin, T.; Liu, J.; Zhao, Z.; Zhao, Y.; Dong, L.; Yang, M.; Zhou, J.; Huo, M. 
Redox Sensitive Hyaluronic Acid-Decorated Graphene Oxide for Photothermally Controlled Tumor-Cytoplasm-Selective Rapid Drug Delivery. Adv. Funct. Mater. 2017, 27, 1604620-n/a.

(19) Chuang, H. F.; Smith, R. C.; Hammond, P. T. Polyelectrolyte Multilayers for Tunable Release of Antibiotics. Biomacromolecules 2008, 9, 1660-1668.

(20) Chung, A. J.; Rubner, M. F. Methods of Loading and Releasing Low Molecular Weight Cationic Molecules in Weak Polyelectrolyte Multilayer Films. Langmuir 2002, 18, 1176-1183.

(21) Mandapalli, P. K.; Labala, S.; Vanamala, D.; Koranglekar, M. P.; Sakimalla, L. A.; Venuganti, V. V. K. Influence of Charge on Encapsulation and Release Behavior of Small Molecules in Self-Assembled Layer-by-Layer Microcapsules. Drug Deliver. 2014, 21, 605-614.

(22) Smith, R. C.; Riollano, M.; Leung, A.; Hammond, P. T. Layer-by-Layer Platform Technology for Small-Molecule Delivery. Angew. Chem. Int. Ed. 2009, 48, 8974-8977.

(23) Etienne, O.; Picart, C.; Taddei, C.; Haikel, Y.; Dimarcq, J. L.; Schaaf, P.; Voegel, J. C.; Ogier, J. A.; Egles, C. Multilayer Polyelectrolyte Films Functionalized by Insertion of Defensin: a New Approach to Protection of Implants from Bacterial Colonization. Antimicrob. Agents Ch. 2004, 48, 3662-3669.

(24) Shukla, A.; Fleming, K. E.; Chuang, H. F.; Chau, T. M.; Loose, C. R.; Stephanopoulos, G. N.; Hammond, P. T. Controlling the Release of Peptide Antimicrobial Agents from Surfaces. Biomaterials 2010, 31, 2348-2357.

(25) Pavlukhina, S.; Lu, Y.; Patimetha, A.; Libera, M.; Sukhishvili, S. Polymer Multilayers with pH-Triggered Release of Antibacterial Agents. Biomacromolecules 2010, 11, 3448-3456.

(26) Guyomard, A.; Dé, E.; Jouenne, T.; Malandain, J.-J.; Muller, G.; Glinel, K. Incorporation of a Hydrophobic Antibacterial Peptide into Amphiphilic Polyelectrolyte Multilayers: A Bioinspired Approach to Prepare Biocidal Thin Coatings. Adv. Funct. Mater. 2008, 18, 758-765.

(27) Cado, G.; Aslam, R.; Séon, L.; Garnier, T.; Fabre, R.; Parat, A.; Chassepot, A.; Voegel, J. C.; Senger, B.; Schneider, F.; Frère, Y.; Jierry, L.; Schaaf, P.; Kerdjoudj, H.; Metz-Boutigue, M. H.; Boulmedais, F. Self-Defensive Biomaterial Coating Against Bacteria and Yeasts: Polysaccharide Multilayer Film with Embedded Antimicrobial Peptide. Adv. Funct. Mater. 2013, 23, 4801-4809.

(28) Faure, E.; Lecomte, P.; Lenoir, S.; Vreuls, C.; Van De Weerdt, C.; Archambeau, C.; Martial, J.; Jerome, C.; Duwez, A.-S.; Detrembleur, C. Sustainable and Bio-Inspired Chemistry for Robust Antibacterial Activity of Stainless Steel. $J$. Mater. Chem. 2011, 21, 7901-7904.

(29) Nordström, R.; Malmsten, M. Delivery Systems for Antimicrobial Peptides. Adv. Colloid Interface Sci. 2017, 242, 17-34.

(30) Hu, J.; Chen, C.; Shengzhong Zhang; Zhao, X.; Xu, H.; Zhao, X.; Lu, J. R. Designed Antimicrobial and Antitumor Peptides with High Selectivity. Biomacromolecules 2011, 12, 3839-3843.

(31) Chen, C.; Hu, J.; Zeng, P.; Pan, F.; Yaseen, M.; Xu, H.; Lu, J. R. Molecular 
Mechanisms of Anticancer Action and Cell Selectivity of Short $\alpha$-Helical Peptides. Biomaterials 2014, 35, 1552-1561.

(32) Chen, C.; Hu, J.; Zeng, P.; Chen, Y.; Xu, H.; Lu, J. R. High Cell Selectivity and Low-Level Antibacterial Resistance of Designed Amphiphilic Peptide G(IIKK) $)_{3} \mathrm{I}-\mathrm{NH}_{2}$. ACS Appl. Mater. Interfaces 2014, 6, 16529-16536.

(33) Narasimhaiah, S.; Ramakrishnan, N. Host-defense Antimicrobial Peptides: Importance of Structure for Activity. Curr. Pharm. Design 2002, 8, 727-742.

(34) Noll, K. S.; Sinko, P. J.; Chikindas, M. L. Elucidation of the Molecular Mechanisms of Action of the Natural Antimicrobial Peptide Subtilosin Against the Bacterial Vaginosis-associated Pathogen Gardnerella vaginalis. Probiotics Antimicro. 2011, 3, 41-47.

(35) Yeaman, M. R.; Yount, N. Y. Mechanisms of Antimicrobial Peptide Action and Resistance. Pharmacol. Rev. 2003, 55, 27-55.

(36) Hancock, R. E.; Rozek, A. Role of Membranes in the Activities of Antimicrobial Cationic Peptides. FEMS Microbiol. Lett. 2002, 206, 143-149.

(37) Bechinger, B. The Structure, Dynamics and Orientation of Antimicrobial Peptides in Membranes by Multidimensional Solid-State NMR Spectroscopy. Biochim. Biophys. Acta 1999, 1462, 157-183.

(38) Lynn, D. M.; Langer, R. Degradable poly(beta-amino esters): Synthesis, Characterization, and Self-Assembly with Plasmid DNA. J. Am. Chem. Soc. 2000, 122, 10761-10768.

(39) Wood, K. C.; Chuang, H. F.; Batten, R. D.; Lynn, D. M.; Hammond, P. T. Controlling Interlayer Diffusion to Achieve Sustained, Multiagent Delivery from Layer-by-Layer Thin Films. Proc. Natl. Acad. Sci. U S A 2006, 103, 10207-10212.

(40) Hummers, W. S.; Offeman, R. E. Preparation of Graphitic Oxide. J. Am. Chem. Soc. 1958, 80, 1339-1339.

(41) Gonçalves, D.; Irene, E. A. Fundamentals and Applications of Spectroscopic Ellipsometry. Química Nova 2002, 25, 794-800.

(42) Wiegand, I.; Hilpert, K.; Hancock, R. E. Agar and Broth Dilution Methods to Determine the Minimal Inhibitory Concentration (MIC) of Antimicrobial Substances. Nature Protoc. 2008, 3, 163-175.

(43) Nguyen, P. M.; Zacharia, N. S.; Verploegen, E.; Hammond, P. T. Extended Release Antibacterial Layer-by-Layer Films Incorporating Linear-Dendritic Block Copolymer Micelles. Chem. Mater. 2007, 19, 5524-5530.

(44) Moskowitz, J. S.; Blaisse, M. R.; Samuel, R. E.; Hsu, H.-P.; Harris, M. B.; Martin, S. D.; Lee, J. C.; Spector, M.; Hammond, P. T. The Effectiveness of the Controlled Release of Gentamicin from Polyelectrolyte Multilayers in the Treatment of Staphylococcus Aureus Infection in a Rabbit Bone Model. Biomaterials 2010, 31, 6019-6030.

(45) Schmidt, D. J.; Moskowitz, J. S.; Hammond, P. T. Electrically Triggered Release of a Small Molecule Drug from a Polyelectrolyte Multilayer Coating. Chem. Mater. 2010, 22, 6416-6425.

(46) Shukla, A.; Avadhany, S. N.; Fang, J. C.; Hammond, P. T. Tunable Vancomycin Releasing Surfaces for Biomedical Applications. Small 2010, 6, 
2392-2404.

(47) Hong, J.; Shah, N. J.; Drake, A. C.; DeMuth, P. C.; Lee, J. B.; Chen, J.; Hammond, P. T. Graphene Multilayers as Gates for Multi-Week Sequential Release of Proteins from Surfaces. ACS Nano 2011, 6, 81-88.

(48) Min, J.; Braatz, R. D.; Hammond, P. T. Tunable Staged Release of Therapeutics from Layer-by-Layer Coatings with Clay Interlayer Barrier. Biomaterials 2014, 35, 2507-2517.

(49) Nakajima, T.; Mabuchi, A.; Hagiwara, R. A New Structure Model of Graphite Oxide. Carbon 1988, 26, 357-361.

(50) Nakajima, T.; Matsuo, Y. Formation Process and Structure of Graphite Oxide. Carbon 1994, 32, 469-475.

(51) Lerf, A.; He, H.; Forster, M.; Klinowski, J. Structure of Graphite Oxide Revisited. J. Phys. Chem. B 1998, 102, 4477-4482.

(52) He, H.; Riedl, T.; Lerf, A.; Klinowski, J. Solid-State NMR Studies of the Structure of Graphite Oxide. J. Phys. Chem. 1996, 100, 19954-19958.

(53) Juban, M. M.; Javadpour, M. M.; Barkley, M. D. Circular Dichroism Studies of Secondary Structure of Peptides. In Methods in Molecular Biology; Shafer, W. M., Ed.; Humana Press Inc: Totowa, NJ, Chapter Antibacterial Peptide Protocols.

(54) Cote, L. J.; Kim, J.; Zhang, Z.; Sun, C.; Huang, J. Tunable Assembly of Graphene Oxide Surfactant Sheets: Wrinkles, Overlaps and Impacts on Thin Film Properties. Soft Matter 2010, 6, 6096-6101.

(55) Cote Laura, J.; Kim, J.; Tung Vincent, C.; Luo, J.; Kim, F.; Huang, J. Graphene Oxide as Surfactant Sheets. Pure Appl. Chem. 2010, 83, 95-110.

(56) Guo, P.; Chen, P.; Liu, M. One-Dimensional Porphyrin Nanoassemblies Assisted via Graphene Oxide: Sheetlike Functional Surfactant and Enhanced Photocatalytic Behaviors. ACS Appl. Mater. Interfaces 2013, 5, 5336-5345.

(57) Kim, J.; Cote, L. J.; Kim, F.; Yuan, W.; Shull, K. R.; Huang, J. Graphene Oxide Sheets at Interfaces. J. Am. Chem. Soc. 2010, 132, 8180-8186.

(58) Feng, Y.; Liu, L.; Zhang, J.; Aslan, H.; Dong, M. Photoactive Antimicrobial Nanomaterials. J. Mater. Chem. B 2017, 5, 8631-8652.

(59) Zhang, Z.; Xu, R.; Wang, Z.; Dong, M.; Cui, B.; Chen, M. Visible-Light Neural Stimulation on Graphitic-Carbon Nitride/Graphene Photocatalytic Fibers. ACS Appl. Mater. Interfaces 2017, 9, 34736-34743. 


\section{Graphical abstract:}

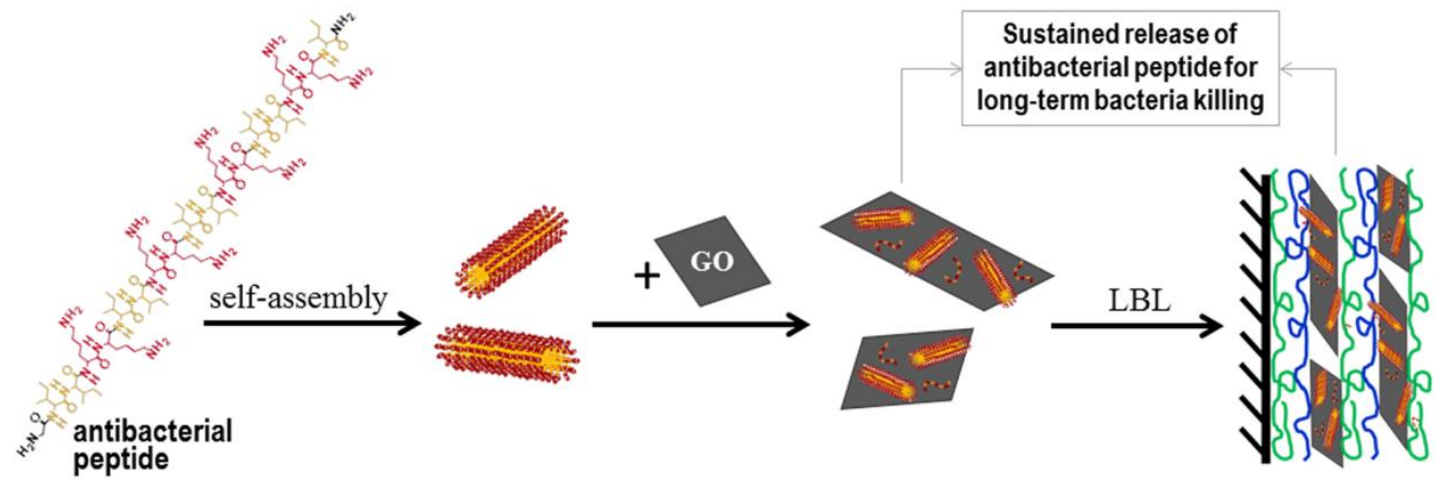




\section{Supporting Information for}

\section{Graphene Oxide/Antimicrobial Peptide Supramolecular Complexes}

\section{for Sustained Release Applications}

Meiwen Cao, ${ }^{* \dagger}$ Wenjing Zhao, Lei Wang, ${ }^{\dagger}$ Ruiheng Li, ${ }^{\ddagger}$ Yu Zhang, ${ }^{\dagger}$ Hai Xu,,${ }^{* \dagger}$ and Jian R. Lu ${ }^{*}+\dot{+}$

${ }^{\dagger}$ State Key Laboratory of Heavy Oil Processing and Centre for Bioengineering and Biotechnology, College of Chemical Engineering, China University of Petroleum (East China), 66 Changjiang West Road, Qingdao 266580, China

${ }^{\ddagger}$ Biological Physics Laboratory, School of Physics and Astronomy, University of Manchester, Schuster Building, Oxford Road, Manchester M13 9PL, U.K.

\section{Corresponding Authors}

* E-mail: mwcao@upc.edu.cn (M. C.); xuh@upc.edu.cn (H.X.); j.lu@manchester.ac.uk (J.R.L) 


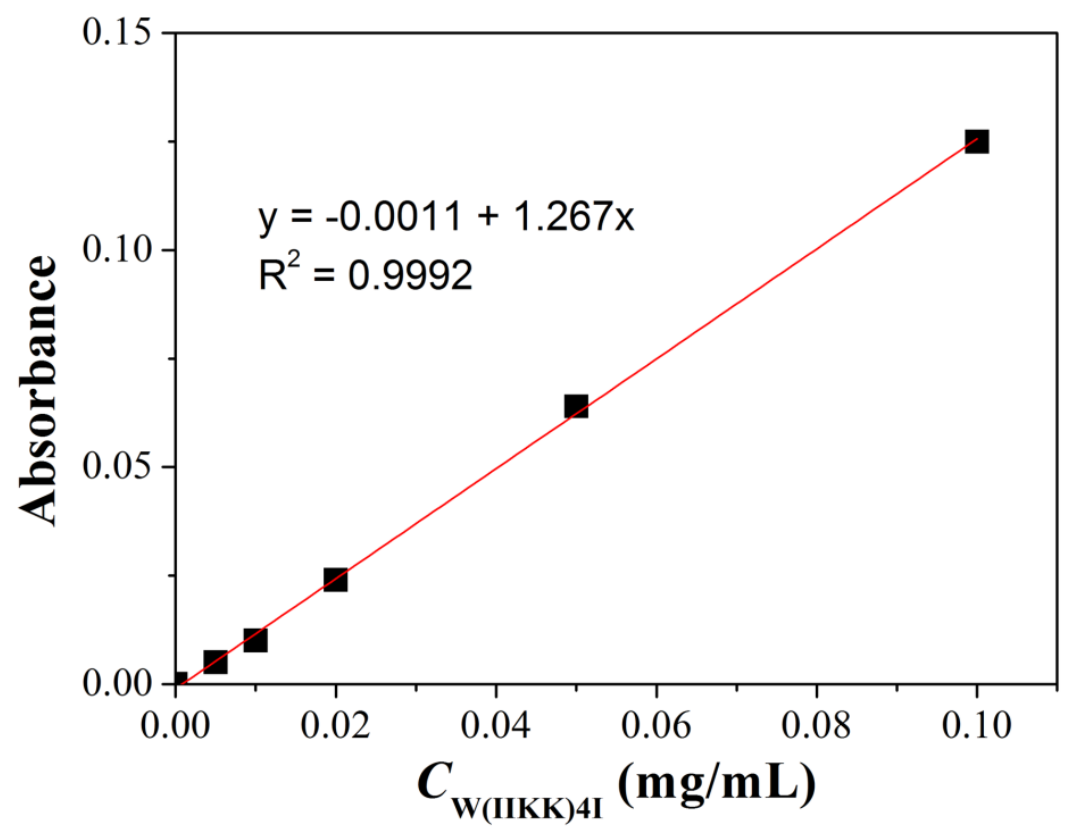

Figure S1. The standard calculation curve derived by linear fitting of the absorbance at $280 \mathrm{~nm}$ of $\mathrm{W}(\mathrm{IIKK}) 4 \mathrm{I}-\mathrm{NH}_{2}$ solutions at different concentrations.

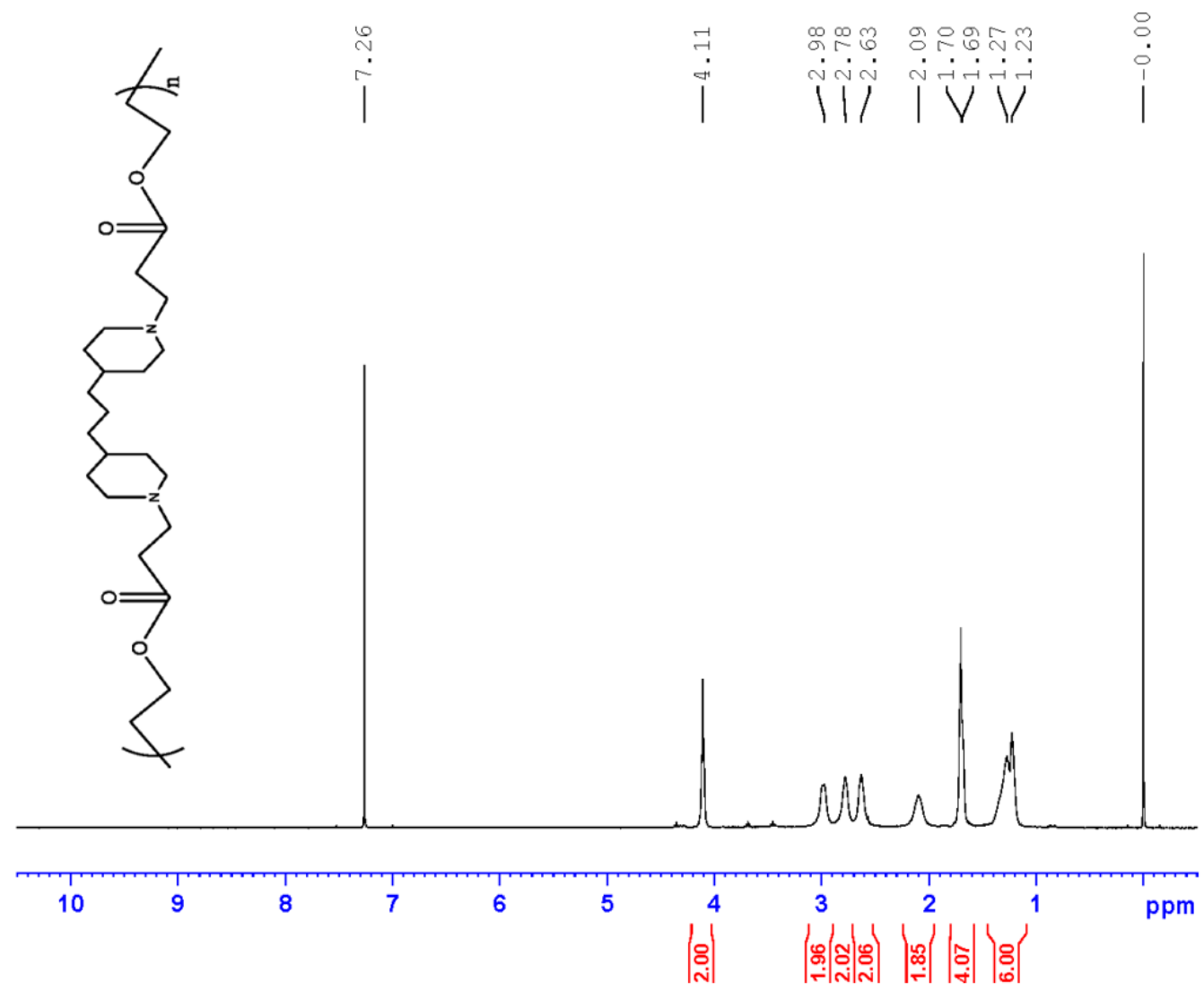

Figure S2. The molecular structure of $\operatorname{poly}(\beta$-amino esters $)$ and the ${ }^{1} \mathrm{H}-\mathrm{NMR}$ results. 

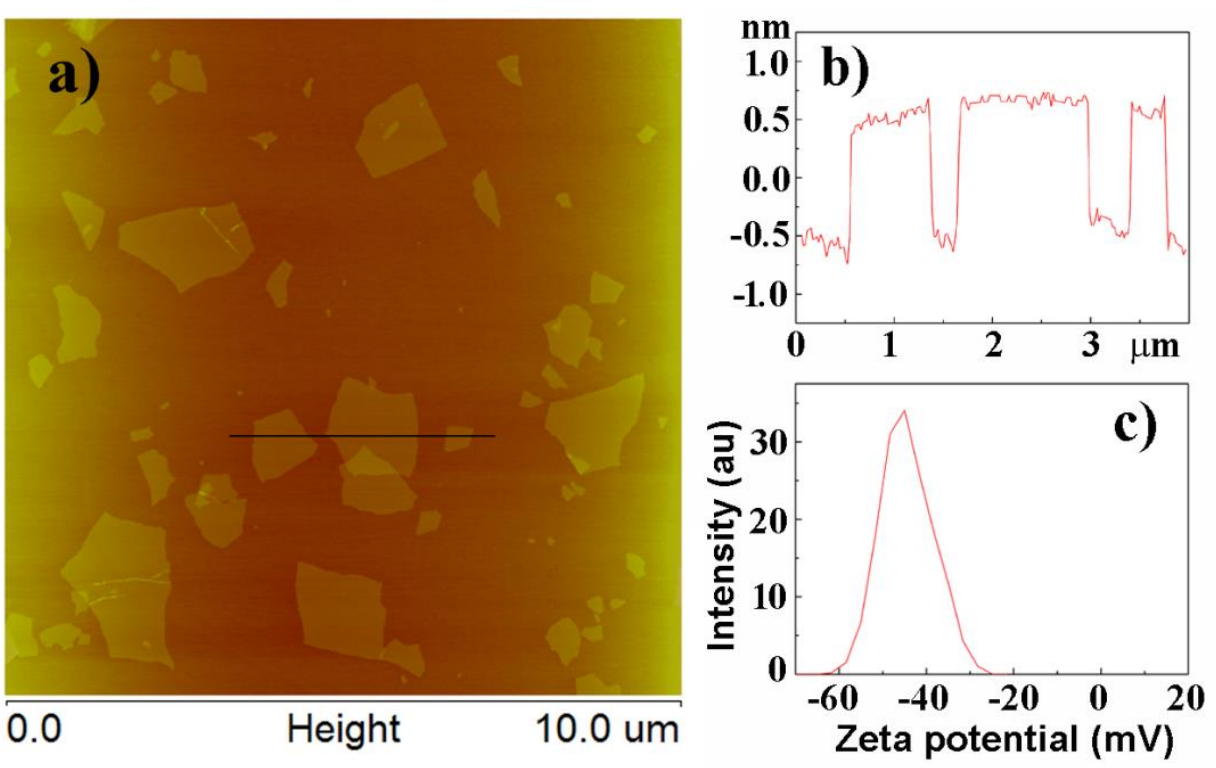

Figure S3. (a) AFM morphology of the GO sheets. (b) Section analysis corresponding to the black line in image a. (c) Zeta potential distribution of the GO sheets in aqueous solution of $0.15 \mathrm{mg} / \mathrm{mL}$.

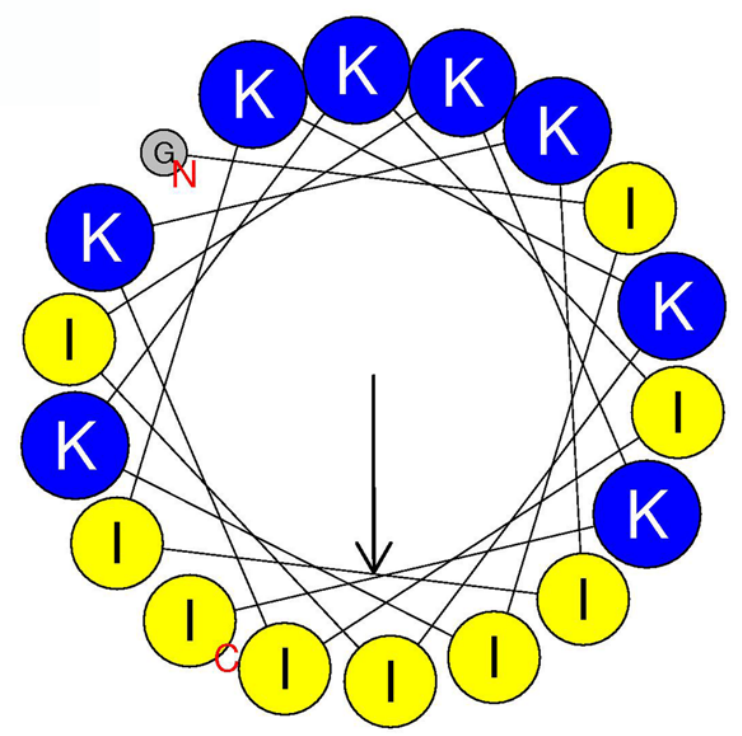

Figure S4. The Schiffer-Edmundson wheel projection of $\mathrm{G}(\mathrm{IIKK})_{4} \mathrm{I}-\mathrm{NH}_{2}$ as drawn by using the online tool at http://heliquest.ipmc.cnrs.fr/cgi-bin/ComputParams.py. 


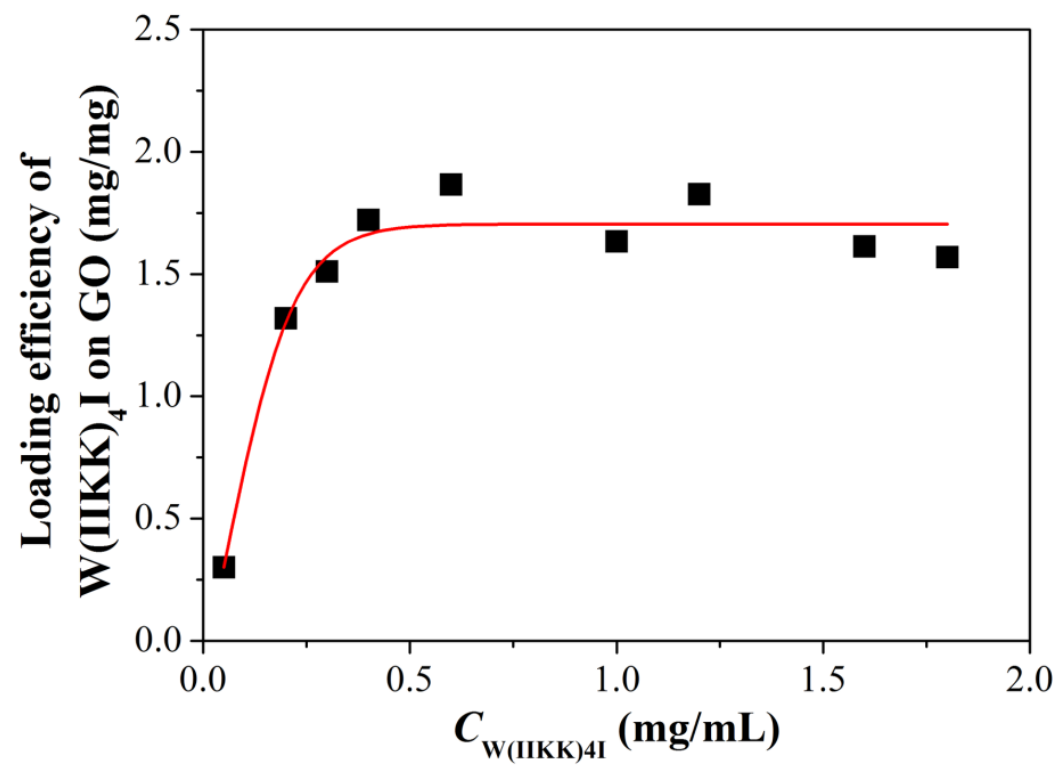

Figure S5. The loading efficiency of $\mathrm{W}(\mathrm{IIKK})_{4} \mathrm{I}-\mathrm{NH}_{2}$ on $\mathrm{GO}$ at different $\mathrm{W}(\mathrm{IIKK})_{4} \mathrm{I}-\mathrm{NH}_{2}$ dosing amount. At saturation $1 \mathrm{mg}$ of $\mathrm{GO}$ can adsorb $1.70 \pm 0.15 \mathrm{mg}$ $\mathrm{W}(\mathrm{IIKK})_{4} \mathrm{I}-\mathrm{NH}_{2}$.

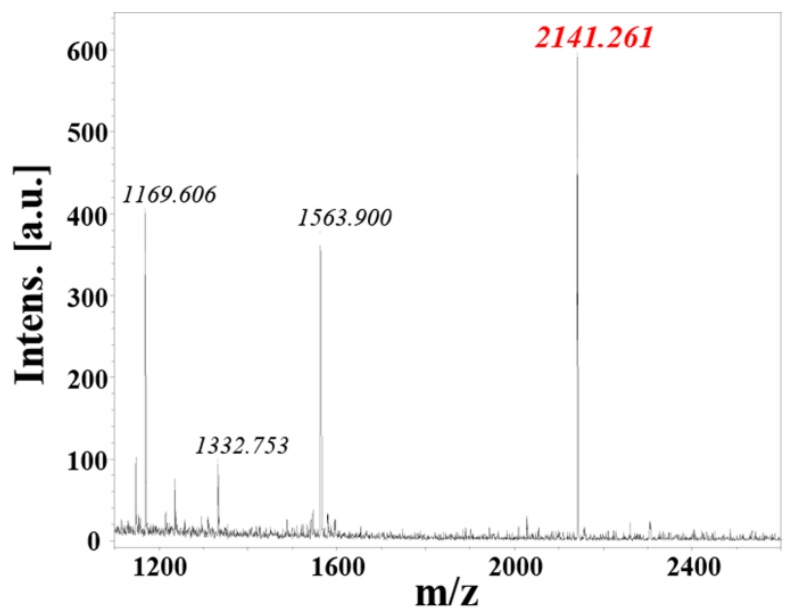

Figure S6. MS spectrum of the solution incubated with the (poly $\left.\beta / \mathrm{PAA} / \mathrm{GO} @ \mathrm{~W}(\mathrm{IIKK})_{4} \mathrm{I}-\mathrm{NH}_{2} / \mathrm{PAA}\right)_{15}$ film for $2 \mathrm{~h}$. Since the theoretical molecular weight of $\mathrm{G}(\mathrm{IIKK})_{4} \mathrm{I}-\mathrm{NH}_{2}([\mathrm{M}])$ is 2117.88 , the signal of 2141.26 is ascribed to $\left[\mathrm{M}+\mathrm{Na}^{+}\right]$peak. 